\title{
Remarkable preservation of microbial mats in Neoproterozoic siliciclastic settings: implications for Ediacaran taphonomic models
}

\author{
Richard H.T. Callow*, Martin D. Brasier
}

Department of Earth Sciences, University of Oxford, Parks Road, Oxford, UK, OX1 3PR.

* Corresponding author: richardc@earth.ox.ac.uk, Telephone +44 1865 272000, Fax +44

1865272072

\begin{abstract}
It is beyond doubt that the appearance of infaunal bioturbation and metazoan biomineralization across the Ediacaran-Cambrian transition irreversibly affected the nature of marine sediment architecture and biogeochemistry. Here we review those changes in relation to their likely effect upon the processes of fossil preservation, especially within siliciclastic sediments. Processes of soft-tissue preservation in siliciclastic settings from the Ediacaran Period, including microbes and microbial mats as well as Ediacaran macrofossils, are here reviewed within this context. Highlighted examples include the exceptional preservation of microbes found in association with wrinkle structures and Ediacaran macrofossils in England and Newfoundland (replicated by silicate minerals) and in the White Sea region of Russia (replicated by iron sulphide). These occurrences show that soft-tissue preservation in siliciclastic settings went well beyond that typical for Ediacaran macrofossils alone and also extended to similar modes of preservation in associated microbes. Using these new observations it can be argued that several existing explanations for Ediacaran fossil preservation can be united within a biogeochemical model that involves evolution of the sediment Mixed Layer across this transition.
\end{abstract}

Keywords: Ediacaran, Taphonomy, Microbial Mats, Macrofossils, Siliciclastic. 


\section{Introduction}

It has long been known that the Ediacaran-Cambrian transition witnessed a radical transformation not only in terms of biomineralization, but also in terms of bioturbation (e.g. Seilacher, 1956). For example, whilst reviewing the increasing depth of burrowing at this time, one of the authors (Brasier, 1979) predicted that "it seems likely that the deposit feeding radiation [ of the Cambrian] ... resulted in great modification of the physical properties of the seafloor with significant biological consequences". Three decades ago, attention was still largely focussed upon the impact of burrowing organisms upon porosity (e.g. Rhoads, 1970) or upon the destructive impact of grazers and burrowers upon 'algal mats' and stromatolites (e.g. Awramik, 1971). Since that time, considerable strides have been made in our understanding of the changes in both the physical and the chemical nature of the uppermost layers of marine sediments, owing to these coeval explosions of bioturbation and biomineralization (e.g. Crimes, 1992; Seilacher \& Pflüger, 1994; Droser et al., 1999; Seilacher, 1999; Bottjer et al., 2000; Droser et al., 2002a; Jensen, 2003; Bengtson, 2004; Dornbos et al., 2004; Droser et al., 2004; Seilacher et al., 2005).

This major change in the nature of sediment substrates during the 'Cambrian explosion' of multicellular animals has been increasingly recognised over the two last decades and has been referred to as the 'agronomic revolution' (Seilacher \& Pflüger, 1994) or the 'substrate revolution' (Bottjer et al., 2000). These biological changes not only had major and irreversible effects on benthic palaeobiology and palaeoecology (Brasier, 1992; Brasier et al., 1994; Seilacher \& Pflüger, 1994; Hagadorn \& Bottjer, 1999; Seilacher, 1999; Bottjer et al., 2000; Dornbos \& Bottjer, 2000; Droser et al., 2002a; Dornbos et al., 2004; Droser et al., 2004; Dornbos et al., 2005; Jensen et al., 2005; Droser et al., 2006) but also on ocean and sediment biogeochemistry (Brasier 1992; Seilacher \& Pflüger, 1994; Gehling, 1999; Mcllroy \& Logan, 1999; Shields, 2002; Droser et al., 2004; Gehling et al., 2005; Bailey et al., 2006). They also appear to have led to a fundamental shift in the nature of fossil preservation (taphonomy) across this interval (e.g. Gehling, 1999; Gehling et al., 2005; Maliva et al., 2005; Droser et al., 2006; Brasier \& Callow, 2007; Brasier et al., in press a).

In this review, we highlight the changes brought about by the expansion of bioturbation near the base of the Cambrian, giving particular consideration to both theoretical and measurable influences upon sediment biogeochemistry. From this review, predictions can then be made about the influence of these changes upon taphonomic processes and the fossil record, particularly of unmineralized tissues. These predictions are examined by means of a review concerning the distinctive phenomenon of bedding plane wrinkle structures or MISS (sensu Noffke et al., 2001), which are often used to infer the presence of widespread microbial mats (biofilms) on the Ediacaran seafloor (e.g. Seilacher \& Pflüger, 1994; Seilacher, 1999; Gerdes et al., 2000; Noffke et al., 2001; 2002; Schieber et al., 2007; Noffke, 2009 this volume). Also considered is the emerging evidence for the preservation of microbial components of the mats themselves, in a variety of taphonomic modes (e.g. Scheiber, 1999; Noffke, 2000; Noffke et al., 2003; $2006 a, b)$. Finally, attention is drawn to a possibly related phenomenon: the preservation of large, soft-bodied organisms such as Charnia and Dickinsonia in volcanic ashes and sands (e.g. Seilacher et al., 1985; Allison \& Briggs, 1991; Gehling, 1991; Allison \& Briggs, 1993; Gehling, 1999).

\section{The role of the sediment Mixed Layer}

Several decades of in situ and laboratory investigations of modern marine sediments means that their biogeochemistry can be relatively well constrained (e.g. Martin \& Sayles, 2003; Burdige, 2006 and references therein). However, it is only more recently that a similar geochemical approach has been considered in the context of ancient sediments, for 
example those from the Precambrian (e.g. Pflüger \& Gresse, 1996; Mcllroy \& Logan, 1999; Pflüger, 1999; Gehling et al., 2005; Bailey et al., 2006). This section outlines a theoretical framework for predicting some aspects of sediment biogeochemistry in ancient siliciclastic settings, and in particular across the Precambrian-Cambrian transition. While some of the features and changes described here are widely known and well understood, they are drawn together to provide an integrated model for understanding the relationships between biology and geochemistry in ancient sediments. Most importantly, this review aims to highlight the impact of these changes on various aspects of the taphonomy of soft-tissues across this interval (e.g. Allison \& Briggs, 1991; Butterfield, 2003).

In the majority of Phanerozoic and modern settings, the upper portion of the marine sedimentary column is processed by aerobic activities, most notably by metazoan bioturbation (the so-called 'mixed layer'; sensu Savrda \& Bottjer, 1989; Bromley, 1996; Droser et al., 2002a; Droser et al., 2004). These processes lead to increased rates of diffusion, processes of vertical and lateral particle mixing and to the flushing of open burrows by bottom waters, known as bioirrigation (e.g. Aller, 1978; 1982; 1984; 1994; Martin \& Sayles, 2003; Burdige, 2006). Aerobic respiration of carbonaceous organic matter $\left(\mathrm{C}_{\mathrm{org}}\right)$ in this layer results in the removal of the majority of reactive materials by microbial and metazoan heterotrophs, using oxygen as an electron acceptor. The exact proportion of $\mathrm{C}_{\text {org }}$ which is removed in this aerobic zone is dependant upon the rate of $\mathrm{C}_{\text {org }}$ supply, but is typically $>70 \%$ and may be as high as $99 \%$ in areas of low sediment and carbonaceous inputs (see Martin \& Sayles, 2003 and references therein). The $\mathrm{CO}_{2}$ released by aerobic respiration leads to a progressive downwards decrease in $\mathrm{pH}$, which in modern sediments may be buffered by the dissolution of calcium carbonate biominerals (Fig. 1).

Below the sediment redox boundary, a stratified series of anaerobic heterotrophic reactions continue the process of the remineralization of $\mathrm{C}_{\text {org }}$ (Fig. 1, Aller, 1982; Jones, 1985; Burdige, 2006). In the absence of free oxygen these anaerobic reactions utilize other electron acceptors (e.g. $\mathrm{NO}_{3}{ }^{2-}, \mathrm{Fe}(\mathrm{III}), \mathrm{Mn}(\mathrm{IV}), \mathrm{SO}_{4}{ }^{2-}, \mathrm{CO}_{2}$ ) for the oxidation of $\mathrm{C}_{\text {org }}$, by reactions including sulphate reduction and methanogenesis (e.g. Aller, 1982; Jones, 1985). These processes and reactions are typically stratified with respect to the energy yield of the reaction, so that electron acceptors with a greater energy yield are utilized first, at shallower depths within the sediment (Fig. 1, Jones, 1985; Martin \& Sayles, 2003; Burdige, 2006). Simple vertical stratification of the redox zones is rare, however, and redox zonation can occur radially around features such as cylindrical burrows, or concentrically around concentrations of carbonaceous matter (Fig. 1, Aller, 1982; Burdige, 2006). The increase in alkalinity produced by some of these reactions (e.g. methanogenesis) also helps to buffer the fall in $\mathrm{pH}$ induced by aerobic respiration and sulphate reduction. Processes of vertical diffusion, bioirrigation and particle mixing (Aller, 1982; Burdige, 2006) allow some products (especially iron and sulphur species) to participate repeatedly as electron donors and acceptors (Martin \& Sayles, 2003; Burdige, 2006).

This efficient system of nutrient recycling means that electron donors $\left(\mathrm{C}_{\text {org }}\right)$ are typically consumed before all the available electron acceptors have been used. The consequence of this is that in most marine sediments, little $C_{\text {org }}$ remains to enter the rock record (Martin \& Sayles, 2003 and references therein). In cases where $C_{\text {org }}$ supply is unusually high or rates of aerobic decomposition are unusually low, there may be potential for the moulding or replacement (permineralization) of unmineralized tissues by diagenetic minerals in the anaerobic microbial reaction zones (e.g. phosphate and pyrite; Berner, 1970; Berner, 1985; Allison, 1988; Ruttenberg, 2003). In the majority of modern sediments, however, carbonaceous materials have largely been extensively degraded by the time that it reaches these zones. It should also be remembered that the process of $\mathrm{C}_{\text {org }}$ remineralization begins in the water column and at the sediment surface, by metazoan and microbial respiration (e.g. Logan et al., 1995). Consequently, the preservation potential of unmineralized tissues in most modern marine sediments is 
extremely low, other than for refractory or processed components (e.g. lignin or faecal pellets).

It is well known that conditions on the Precambrian seafloor appear to have been significantly different from those of the Phanerozoic, and this topic has been addressed at length in the geological literature (Fig. 1, Seilacher, 1956; Brasier, 1979; Brasier, 1992; Seilacher \& Pflüger 1994; Droser et al., 1999; Hagadorn \& Bottjer, 1999; Mcllroy \& Logan, 1999; Bottjer et al., 2000; Droser et al., 2002a; Jensen, 2003; Droser et al., 2004; Jensen et al., 2005). In summary, it should be noted that without significant bioturbation (Mcllroy \& Logan, 1999), and in the presence of widespread benthic microbial mats (Seilacher \& Pflüger, 1994; Seilacher, 1999), the aerobic mixed layer would have been limited to the maximum extent of solute diffusion beneath a sharp sediment-water interface and anoxic conditions could have been present just millimetres beneath the sediment-water interface (e.g. Gehling, 1999; Bottjer et al., 2000; Mcllroy \& Logan, 1999; Bailey et al., 2006). That being so, there was likely no disruption of vertical redox stratification by features such as burrows (Aller, 1982; Mcllroy \& Logan, 1999). Consequently, the sharp redox boundary would have lain closer to the sediment surface and the anaerobic heterotrophic reaction zones would then have been compressed into shallower depths within the sediment (Fig. 1, Mcllroy \& Logan, 1999; Bottjer et al., 2000; Bailey et al., 2006). This thin and shallow aerobic mixed layer may have been further compressed by the sealing effects of benthic microbial mats, which reduced sediment permeability (e.g. Allison, 1947) and limited diffusion of dissolved oxygen at the sediment-water interface (e.g. Gehling, 1999; Barth, 2003; Noffke et al., 2003).

In the modern ocean, sediments with limited bioturbation tend to be associated with low sedimentation rates and low rates of $C_{\text {org }}$ supply (e.g. Boudreau, 1994). In the Precambrian ocean, however, intensive macrofaunal bioturbation is believed to have been universally insignificant or absent (e.g. Droser et al., 1999; Mcllroy \& Logan, 1999; Seilacher, 1999; Bottjer et al., 2000; Droser et al., 2002a; Jensen, 2003; Droser et al., 2004; Jensen et al., 2005), regardless of the rates of sedimentation or $C_{\text {org }}$ supply. A consequence of a shallower sediment mixed layer in the Ediacaran Period, would therefore appear to be that carbonaceous material would typically have undergone less microbial degradation by the time that it reached the potential zones of preservation (mineralization) within the sediment (e.g. sulphate reduction zone). Consequently, it can be predicted that in the Ediacaran Period, the potential for the replacement and permineralization of undegraded, unprocessed carbonaceous materials, by diagenetic minerals including pyrite and phosphate would have been greater than in the Phanerozoic. This elevated preservation potential is likely to have been further enhanced by the lack of zooplankton (e.g. Butterfield, 1997; Rigby \& Milsom, 2000) or motile benthic scavengers and deposit feeders (e.g. Seilacher, 1999; Bottjer et al., 2000). It has been proposed that faecal packaging by zooplankton may have increased the rapid supply of $\mathrm{C}_{\text {org }}$ to sediments owing to the bypassing of microbial decomposition zones in the water column (e.g. Logan et al., 1995). This review focuses on the preservation of unprocessed, pristine materials (such as those outlined by Brasier \& Callow, 2007), rather than carbonaceous matter in the form of faecal remains.

\subsection{The 'Mixed Layer Model'}

A diagram is shown in Figure 1, here called the 'Mixed Layer Model' which aims to integrate and build upon recent contributions to the study of the biological revolutions and their consequences, across the Ediacaran-Cambrian boundary (see above section 2). In particular, this model considers the impact of the major biological revolutions on taphonomic processes across this interval. The key feature of this model is that during the Precambrian, from the late Archean until the Ediacaran-Cambrian boundary interval, nearsurface diagenetic processes including phosphatization and pyritization likely occurred 
closer to the sediment surface than at later times (Mcllroy \& Logan, 1999; Orr et al., 2003; Bailey et al., 2006), leading to the earlier and more rapid permineralization of unprocessed carbonaceous materials (e.g. Brasier et al., in press a). In addition to this, the model also predicts that without bioturbation, pore-water solute concentrations (e.g. carbonate or silicate ions) could have become elevated at shallow depths within the sediment (e.g. Mcllroy \& Logan, 1999), allowing high levels of ionic saturation to develop within unbioturbated sediments. High concentrations of these ions within sediment porewaters may also have been favoured by their elevated concentrations in the Precambrian seawater, owing in part, to the lack of significant biomineral sinks (e.g. Maliva et al., 1989; 2005; Siever, 1992; Porter \& Knoll, 2000; Shields, 2002; Perry \& Lefticariu, 2003). The proposed high concentrations of dissolved silica in Ediacaran seawater, and the prediction for a shallow depth of the zone of secondary silicification are both supported by evidence for abundant silica precipitation in shallow marine environments (Knoll, 1985) and for the exceptional preservation of microbiotas within cherts (e.g. Bitter Springs chert; Barghoorn $\&$ Schopf, 1965).

It can be argued that these factors are likely to have encouraged the early diagenetic precipitation of authigenic silicate minerals (e.g. phyllosilicate clay minerals such as smectites; Worden \& Morad, 2003) from seawater, onto both organic templates (e.g. Konhauser \& Urrutia, 1999) and siliciclastic substrates (Mapstone \& Mcllroy, 2006). The precipitation of such clay minerals could have been catalyzed by heterotrophic microbial reactions (McMahon et al., 1992; Worden \& Morad, 2003). These precipitates may, in turn, have helped to induce the rapid cementation of sediments at shallow depths during early diagenesis, much like those microbially-mediated processes of carbonate lithification discussed by Chafetz \& Buczynski (1992). This mineralization may then be able to account not only for the remarkable permineralization of cellular materials by silica/silicate (see section 3.1), but it may also help to explain some paradoxical aspects of Ediacaran macrofossil preservation, through the moulding of organisms by siliciclastic sediments (see section 4). Importantly, this model may also help to explain a range of other unusual phenomena, including paradoxical 'molar-tooth' carbonate precipitates, which have hitherto been linked to elevated ionic (carbonate) concentrations in Neoproterozoic seawater (Shields, 2002).

The 'agronomic' or 'substrate revolution' which began at the base of the Cambrian and continued through the Cambrian (Droser \& Bottjer, 1988), irreversibly changed this unique set of conditions in most marine settings (Fig. 1, Seilacher \& Pflüger 1994; Hagadorn \& Bottjer, 1999; Bottjer et al., 2000; Droser et al., 2002a; Jensen, 2003; Orr et al., 2003; Droser et al., 2004; Dornbos et al., 2004; 2005; Droser et al., 2006). In addition, the appearance of silica biomineralization (e.g. hexactinellid sponges and radiolarian rhizopods; Bengtson, 2004) is predicted to have reduced oceanic silica concentrations (Perry \& Lefticariu, 2003; Maliva et al., 2005). The onset of significant infaunal bioturbation (Seilacher, 1956; Crimes, 1992; Seilacher \& Pflüger, 1994; Mcl Iroy \& Logan, 1999; Droser et al., 2002a; Jensen, 2003; Droser et al., 2004), increased the average depth of the mixed layer and therefore reduced the concentration of ions in porewaters (e.g. silicate and carbonate) as well as increasing the average depth of processes leading to pyritization and phosphatization of carbonaceous materials (Fig. 1, Mcllroy \& Logan 1999; Orr et al., 2003; Bailey et al., 2006). Consequently, it is suggested that in Cambrian and younger sediments, carbonaceous materials have typically undergone more aerobic decomposition by the time that they reach the potential zones of authigenic mineralization. In addition to this, the appearance of zooplankton and metazoan scavengers greatly increased the biological processing of organic matter in the water column and at the sediment surface. This decrease in both the quality and abundance of soft tissue preservation is also well documented by changes in the preservation of microand macrofossils within chert, phosphate, carbonate and carbonaceous-pyritic lagerstätten (Butterfield, 2003; Orr et al., 2003; Brasier \& Callow, 2007; Brasier et al., in press a). 
The Mixed Layer Model (Fig. 1) may therefore yield important clues for the understanding of the taphonomy of soft tissues within Ediacaran siliciclastic environments, and is tested below by examining the twin paradoxes of the preservation of microbial mats and their components and macrofossil preservation in the Ediacaran Period.

\section{Ediacaran Microbial Mats}

Wrinkle structures or MISS (see Noffke 2000; Noffke et al. 2001; Noffke 2009 this volume) such as 'old elephant skin' texture (e.g. Gehling, 1999), as well as other sedimentary structures of putative microbial origin, including pustules, sinuous cracks and sand chips (Fig. 2, Schieber, 1999; Gerdes et al., 2000; Noffke et al., 2001; Schieber et al., 2007), have been recognised from siliciclastic bedding planes ranging from the Archean (Noffke et al., 2003; 2006, a, b; Noffke, 2007; Noffke et al., 2008; Noffke, 2009 this volume) to the present day (Gerdes et al., 2000; Noffke et al., 2001; Schieber et al., 2007; Noffke, 2009 this volume). As applied here, the term 'microbial' refers to organisms ranging from bacteria and archaea, to protozoans, algae (protoctists) and fungi (e.g. Glaizer \& Nikaido, 1995). In this paper, therefore, the term 'microbial mat' therefore refers to any macroscopic carbonaceous film (i.e. biofilm or a biomat) growing at a solid interface, constructed or inhabited by individual microorganisms and their extracellular products that can only be studied microscopically (see Krumbein et al., 2003 and Levit \& Krumbein, 2003 for discussion and further definitions and usage of the terms biofilm, biodictyon, biomat and microbial mat). This broad definition is of particular utility across the Ediacaran-Cambrian transition because it allows the role of bacterial (e.g. cyanobacterial) and archaeal as well as eukaryotic algal or protozoan components and the term implies no comparison with microbial mats from modern shallow water peritidal settings. In Phanerozoic and recent sediments microbial mats are most commonly found in environments where metazoan grazing and bioturbation are suppressed, for example by physical or chemical factors (e.g. Pflüger, 1999).

In contrast, the abundance of wrinkle structures and related features on Precambrian siliciclastic bedding planes, has led to acceptance of the notion that microbial mats were much more widespread on the seafloor at that time, so that they had were more likely to be preserved (Fig. 2, Seilacher \& Pflüger, 1994; Pflüger \& Gresse, 1996; Seilacher, 1999; Pflüger, 1999). The preponderance of such markings in the Ediacaran Period has also led to the suggestion of a link between microbial mats and Ediacaran macrofossil preservation (Gehling, 1991; 1999; Gehling et al., 2005; Mapstone \& Mcl Iroy, 2006).

The comparison of ancient wrinkle structures with features from modern microbial mats (e.g. Hagadorn \& Bottjer, 1997; Noffke et al., 2001; Schieber et al., 2007; Noffke 2009 this volume) has revolutionized the study and understanding of ancient microbial communities and has led to the introduction of terms such as 'Microbially Induced Sedimentary Structures' (MISS) for their description and classification (Noffke et al., 2001). In spite of similarities between some ancient wrinkle structures and structures formed by wholly abiogenic processes (e.g. load casts or desiccation features; e.g. McLoughlin et al., 2008) there are now a number of well established criteria which can be used to confirm the interpretation of ancient wrinkle structures as biological in origin (see Schieber, 1999; Noffke 2000; Noffke et al., 2002; 2003; 2006a, b; Noffke 2009 this volume).

There is also a growing number of where mat-building microbes are preserved within siliciclastic sediments, sometimes alongside MISS (e.g. Noffke 2000; Noffke et al. 2002; 2003; 2006a, b; Noffke, 2009 this volume), or even in association with macroscopic fossils (Fig. 3 ). These microfossils can be preserved in a number of taphonomic modes, including as carbonaceous sheaths and films and as pyritized remains (e.g. Fedonkin \& 
Waggoner, 1997; Noffke et al., 2003; Noffke et al., 2006a, b; Grazhdankin \& Gerdes, 2007; Callow \& Brasier, 2009). Importantly they can be found preserved in preservational styles that are similar to those of Ediacaran macrofossils (i.e. as moulds and casts within siliciclastic sediments). This not only supports a biological mode of formation for these ancient wrinkle structures (see Schieber, 1999; Noffke et al., 2002; Noffke et al., 2003; 2006a, b; Noffke, 2009 this volume) but may be important for investigating the connections between microbes, mats and macrofossil preservation.

\subsection{Preservation of mats and microbes}

\subsubsection{The White Sea Region, Russia}

An assemblage of wrinkle structures is known from the shallow water, fossiliferous sediments of the White Sea region of Russia (c. 555 Ma, Martin et al., 2000), where they have been used to infer the presence of ancient microbial mats (e.g. Fedonkin, 1992; Dzik, 2003; Grazhdankin, 2004). But here, in addition to MISS, direct evidence for microbial mats can also be observed. For example, Steiner \& Reitner (2001) extracted carbonaceous biomat fragments from sediments marked with 'old elephant skin' texture (sensu Gehling, 1999) and also recovered carbonaceous and pyritized filaments, which were interpreted as cyanobacteria (Steiner \& Reitner, 2001). It is possible to observe clusters of pyritized threads on bedding planes, often closely associated with fossils such as Dickinsonia (Fig. 3), which have previously been interpreted as microbial filaments of unconfirmed biological affinity (Fedonkin \& Waggoner, 1997; Gehling et al., 2005; Grazhdankin \& Gerdes, 2007). The observations shown in Figure 3 support the previous interpretations of these threads as three-dimensional, exceptionally preserved microbial filaments and demonstrate that they are non-septate, circular in cross section and are typically c. $100 \mu \mathrm{m}$ in width, and up to several millimetres in length. No branching or connections between filaments have been observed in this study (Fig. 3), although branching has been reported by others (Grazhdankin \& Gerdes, 2007, fig. 3B). Observations of parallel oriented filaments may reflect palaeocurrent flow or even possibly the internal organization of a microbial colony (Grazhdankin \& Gerdes, 2007).

These observations support the inferred link between microbial mats and sedimentary wrinkle structures in the White Sea region and may also support the 'death mask' hypothesis and the link between microbial mats and early diagenetic pyritization (Gehling, 1999; Dzik, 2003; Mapstone \& Mcllroy, 2006). Pyrite nucleation is likely to have been facilitated by sulphate reducing bacteria (e.g. Berner, 1969; 1970; 1985; Canfield \& Raiswell, 1991). Observations of abundant pyritization of undegraded soft tissues appears to be compatible with the predictions discussed earlier, and also with those of the 'death mask' model of Gehling (1999; see below section 4.1), that a shallow and thin sediment mixed layer, perhaps beneath microbial mats, allowed a relatively shallow zone of sulphate reduction (pyritization), which facilitated the mineralization of organic filaments prior to significant decomposition.

\subsubsection{The Longmyndian Supergroup, England}

The late Ediacaran-age siliciclastic sediments of the Longmyndian Supergroup (c. 567-556 $\mathrm{Ma}$, Compston et al., 2002) contain a variety of distinctive bedding plane markings, including those described in the first ever report of macrofossils from the Precambrian ('Arenicolites', Salter, 1856; 1857). More recent investigations have interpreted this suite of distinctive markings as ranging from microbially induced sedimentary structures to body or trace fossil taxa (see Mcllroy et al., 2005 for recent review). No 'frondose' Ediacaran macrofossils have yet been found in these sediments, although a variety of macroscopic bedding plane 'discs' have been identified (cf. Beltanelliformis minutae, Mcl Iroy et al., 2005). The Longmyndian Supergroup is of particular interest for this study of microbial mats in the Ediacaran Period, not only because of its abundance of putatively 
microbially induced structures on bedding planes but also because of its exceptionally preserved microbial remains (e.g. Peat, 1984).

Petrographic thin sections through carbonaceous siltstones of the Lightspout Formation (see Mcl Iroy et al., 2005 and references therein) reveal abundant carbonized microbial filaments, $<20 \mu \mathrm{m}$ in diameter (Callow \& Brasier, 2009), similar to those described by Peat (1984), which show no evidence for branching and are non-septate and untapered. They are commonly found in parallel to sub-parallel orientations and form interwoven mat laminae (Fig. 4A, Callow \& Brasier, 2009). Associated wrinkle structures on the base of the filament-bearing horizons are also interpreted as microbial in origin (cf. Noffke 2000; Noffke et al., 2002; 2003; 2006a, b; Noffke, 2009 this volume). No evidence for pyritic veneers or horizons in association with these microbes or wrinkle-marked beds has been found in this investigation.

Examination of both new collections and J.W. Salter's historic material (see Salter, 1856; 1857) has revealed a variety of exceptionally preserved, filamentous and discoidal microbial fossils from siltstone bedding planes (Fig. 4-5, Callow \& Brasier, 2009). The most common structures are long, thin (c. $20 \mu \mathrm{m})$, non-septate, untapered threads, which can show unequivocal branching structures. The filaments can be observed in low densities where they tend to show no preferred orientations, are commonly sinuous or sharply bent and are often seen to intertwine and overlap. Alternatively, they can be found in high densities within very thin sedimentary laminae $(<1 \mathrm{~mm})$ where randomly oriented, straight filaments form a dense, interlocking microbial mesh (Fig. 4B). These fossils are preserved in gentle positive relief, permineralized by a white mineral (Fig. 4BC), which Energy Dispersive X-ray (EDX) spectrometry has shown to be an iron and potassium aluminosilicate. Although the exact mineralogy remains uncertain, a phyllosilicate seems likely (Callow \& Brasier, 2009; see also Cohen et al., 2009). The replication of unmineralized tissues by aluminosilicate minerals is otherwise unusual in the Phanerozoic (e.g. the Ordovician Soom Shale; Gabbott et al., 2001) and may be reliant upon relatively high concentrations of silicate ions, induced by microbially catalyzed reactions (McMahon et al., 1992; Callow \& Brasier, 2009).

In addition to these long, thin filaments, much broader filaments are known from the same bedding planes (Fig. 4C, Callow \& Brasier, 2009). These broader filaments may be up to several hundred microns in diameter and 1-2mm in length (Fig. 4C). They occur alongside large (up to $500 \mu \mathrm{m}$ diameter) circular or discoidal structures (Fig. 4D), which can often be found in clusters of up to 20 individuals. These larger microbial features are also white in colour and have an aluminosilicate composition.

Finally, thread-like structures $(>100 \mu \mathrm{m}$ in diameter) can be found in positive or negative relief on Longmyndian bedding planes (Fig. 5). Unlike the permineralized filaments described above, these markings are preserved as impressions and moulds on bedding planes within the fine-grained siliciclastic sediment itself, much like the preservation of Ediacaran macrofossils (see section 3). These bedding plane markings are often closely associated with, and may even overlie, macroscopic features such as those discs referred to Beltanelliformis minutae Mcllroy, which are often preserved in the opposite sense of relief to the filaments (Fig. 5A). The largest threads can be over a centimeter in length (Fig. 5), may be straight to highly sinuous in morphology and tend to show branching structures and overlapping relationships. These observations have led to the suggestion that these structures are three-dimensionally preserved microbial filaments, or bundles of filaments, rather than simple abiogenic artefacts or microscopic trace fossils (see Callow \& Brasier, 2009).

This evidence not only supports the existence of a diverse microbial community (Callow \& Brasier, 2009) but also a microbial origin for the associated wrinkle structures (cf. Noffke 2000; Noffke et al., 2002; 2003; 2006a, b). Interestingly, these microbes are preserved in three distinct taphonomic modes; as carbonaceous remains; as permineralized aluminosilicate replicas; and as bedding plane impressions and moulds. Cohen et al. (2009) summarize various possible taphonomic mechanisms for the 
preservation of organic-walled tubular Vendotaenia, which is known as carbonaceous remains from around the world during the latest Ediacaran (Cohen et al., 2009, fig. 6). This may be comparable with the taphonomic processes operating in the Longmynd. Together, these observations are consistent with the predictions of the Mixed Layer Model given above: that the preservation potential of unmineralized remains (including microbes) was greater across a range of environments at this time, and that silicate precipitation onto both organic substrates and siliciclastic templates is likely to have been important. If so, it is expected further examples of such preservation should come to light in other siliciclastic deposits of Ediacaran age.

\subsubsection{Charnwood Forest (England) and the Conception Group (Newfoundland)}

A wide variety of MISS occur abundantly in the deep water, sub-photic zone, fossiliferous sediments of the Avalonian terrane from Charnwood and southeastern Newfoundland (Fig. 2A-B, Wood et al., 2003; Narbonne, 2005; Narbonne, 2007). Until now, however, there have been no reports of potential mat-building microbial fossils from these sediments. New observations reported here indicate the preservation of filamentous microbes within the Drook Formation (c. $575 \mathrm{Ma}$, Bowring et al., 2003) of southeastern Newfoundland, in association with what have been described as the oldest 'Ediacaran-type megafossils' I vesheadia lobata, Thectardis avalonensis and Charnia wardi, all living within a deep water, turbidite setting, well beneath the photic zone (Bowring et al., 2003; Narbonne \& Gehling, 2003; Wood et al., 2003; Narbonne, 2005; Narbonne et al., 2005 and references therein).

Sinuous filamentous ridges, $>1 \mathrm{~mm}$ in diameter and up to $3 \mathrm{~cm}$ in length, occur sporadically on fine-grained turbidite bedding planes often in association with iron staining (Fig. 6A) and overlain by layers of volcanic ash (Narbonne et al., 2005). The ridges usually occur in random orientations in positive epirelief and occasionally show evidence for branching, overlapping and cross-cutting relationships (Fig. 6A). In addition, parallel to sub-parallel oriented filaments ( $<1 \mathrm{~mm}$ in diameter) can be observed, many of which show a distinctive hook-shaped termination at one end (Fig. 6B), which is an interesting and potentially diagnostic feature. This set of observations helps to eliminate their origin from abiogenic mechanisms such as current lineations (cf. 'Arumberia', see Mcllroy \& Walter, 1997), tool marks or even tectographs (e.g. Seilacher, 2007). A biogenic origin therefore appears probable and it is suggested that these features may represent microbial filaments. The possible affinities of these markings remain unresolved as yet, although heterotrophic or chemoautotrophic bacteria and fungi may provide possible analogues (Brasier et al. in press b). Attention is also drawn to the similarities between the larger filaments from the Drook Formation (Fig. 6A) and the tubular, possibly algal fossils of Vendotaenia, which are known from sediments worldwide during the Ediacaran Period (see Cohen et al., 2009).

These discoveries support a connection between microbes and various wrinkle structures on bedding planes from the Avalon terrane. The preservation of filamentous thread-like features as impressions, moulds and casts, in a style of preservation that is remarkably similar to that of coeval fossils such as Charnia wardi (Narbonne \& Gehling, 2003) also reinforces the observations from other localities that this style of fossil preservation in siliciclastic settings appears to extend from macrofossils to microfossils during the Ediacaran Period.

\subsubsection{Other Ediacaran lagerstätten}

Bedding planes from the Ediacara Member (Rawnsley Quartzite) of the Flinders Ranges, South Australia typically contain a variety of fossils such as Dickinsonia, alongside wrinkle structures including 'old elephant skin' (Fig. 2C, Gehling, 1999), as well as other putatively microbial features including pustules and over-steepened ridges (see Hagadorn \& Bottjer, 1997; 1999; Schieber et al., 2007). Many of these features compare closely with modern MISS (see Schieber et al., 2007), although no fossilized microbes are likely to be identified 
within the South Australian sediments owing to the coarse grain size of sediments in this setting.

The majority of macroscopic fossils from the Nama Group are preserved as threedimensional moulds within sands (Saylor et al., 1995; Narbonne et al., 1997), without associated microbial mats. That cannot be because microbial mats were rare in this region because the succession is rich in biological stromatolites and thrombolites in coeval carbonate environments (e.g. Grotzinger et al., 2000), as well as abundant MISS and fossil filaments in temporally equivalent siliciclastic settings (e.g. Noffke et al., 2002). All this suggests that microbial mats were widespread and abundant on the Nama Group seafloor (Noffke et al., 2002), although their role in the preservation of the Nama macrofossil biota remains open to question (see below section 4).

\subsection{Synthesis}

Together with new information presented herein, this review of wrinkle structures and preserved microbes in the Ediacaran Period highlights a number of important observations. Firstly, it helps to confirm a microbial mode of formation of elephant skin texture in a number of settings (White Sea region, the Longmyndian Supergroup and the Drook Formation). Secondly, it shows that microbial fossils could be preserved in the same modes as associated Ediacaran macrofossils. Taken together, it then becomes clear that the remarkable preservation of soft tissues in Ediacaran siliciclastic substrates was not limited to macrofossils but also extended to microbial remains. Most importantly, some examples of microfossil preservation - such as phyllosilicate casts - are difficult to explain using existing taphonomic models for the Ediacara biota (see section 4).

The model shown in Figure 1, predicts that high levels of ionic saturation at shallow depths within unbioturbated sediments may have played a role in inducing the precipitation of a variety of diagenetic minerals at shallow sediment depths, including pyrite (Figure 3 ) and silicates. This arguably facilitated the relatively rapid lithification of sediments, which may help to account for the preservation of both macrofossils and microbial fossils as impressions and moulds on the same bedding planes. High silicate ion concentrations may likewise help to account for the permineralization of delicate microbial remains, particularly given the known affinity of silicates (e.g. phyllosilicates) for carbonaceous materials (e.g. Konhauser \& Urrutia, 1999).

These predictions of the Mixed Layer Model are therefore broadly consistent with observations of microbial taphonomy from the Ediacaran. This model may therefore provide us with an explanation applicable to the wide variety of preservational styles seen in unmineralized materials of the Ediacaran Period. It is not possible, as yet however, to conclusively determine the role of microbial mats in inducing the biogeochemical gradients required for the preservation of soft tissues.

\section{Implications for macrofossil preservation}

The Mixed Layer Model makes a number of predictions that may be relevant to macrofossil preservation in the Ediacaran Period and which may add to the significant advances already made in understanding Ediacaran macrofossil preservation (e.g. Gehling, 1999; Gehling et al., 2005; Narbonne, 2005). The characteristic biota of the Ediacaran has been regarded as soft-bodied organisms akin to jellyfish and worms (e.g. Donovan \& Lewis, 2001), although it can be argued that no members of the modern animal phyla can be recognised with certainty at this time (Brasier \& Antcliffe, 2004; Antcliffe \& Brasier, 2007; Brasier \& Antcliffe, 2009, Brasier 2009). Interpretations of the fossils range from members of the modern animal phyla (e.g. Glaessner, 1984), to members of an extinct group (the Vendobionta; Seilacher, 1992), or unicellular protists (Seilacher et al., 2003), or even fungi (Peterson et al., 2003) or lichens (Retallack, 1994). Our interpretations of the 
evolutionary relationships of these fossils lead us to use the taxonomic grouping Petalonamae Pflug (see Pflug 1972) to describe the various fossils of the Ediacaran Period, such as Charnia, Pteridinium and even, in our view, Dickinsonia (Fig. 7).

The preservation of such petalonamaean macrofossils within siliciclastic sediments and volcanic ashes (often in association with pyrite) from a range of depositional environments has been equally difficult to explain (e.g. Misra, 1971; Saylor et al., 1995; Gehling, 1999; Carney et al., 2000; Gehling, 2000; Wood et al., 2003; Grazhdankin, 2004; Narbonne, 2005; Mapstone \& Mcllroy, 2006). Their rarity in non-siliciclastic strata is noteworthy, given the abundance of other unmineralized remains in phosphatic or carbonaceous lagerstätten, although occurrences as carbonaceous films and within carbonate sediments provides palaeobiological insights and may help us to understand preservational biases between assemblages (see Steiner \& Reitner, 2001; Narbonne, 2005; Xiao et al., 2005; Grazhdankin et al., 2008). The scarcity of comparable preservation in siliciclastic sediments at later times may also be significant (e.g. Seilacher et al., 1985; Allison \& Briggs, 1991; Gehling, 1991; Allison \& Briggs, 1993; but see also Crimes \& Mcllroy, 1999; Hagadorn et al., 2000; Bell et al., 2001; Samuelsson \& Butterfield, 2001; Hagadorn et al., 2002; Alessandrello \& Bracchi, 2003; Conway-Morris \& Grazhdankin, 2005). Different localities and depositional settings also tend to show distinctive styles of preservation, which has led to a number of possible explanations which are considered briefly below.

\subsection{Taphonomic Modes}

One explanation for the preservation of fossils in negative relief on bedding plane soles ('Flinders-style' preservation of Narbonne, 2005) has been that organisms possessed a resistant external integument (Wade, 1968; Seilacher, 1984; 1989; J enkins et al., 1992; Retallack, 1994; Crimes et al., 1995; Retallack, 2007), although observations of overfolded, bent and torn specimens (Runnegar, 1982; Gehling et al., 2005; Brasier \& Antcliffe, 2009) can be taken to suggest otherwise (Fig. 2D). Another explanation, based on field and laboratory study of fossiliferous surfaces which preserve both macrofossils and associated biomats, invoked the rapid lithification of the sediment by the precipitation of iron sulphide 'death masks' in the overlying bed (Gehling, 1991; 1999; Gehling et al., 2005). I ron sulphides form in suitable pH and Eh conditions (Berner, 1970; Canfield \& Raiswell, 1991), which are suggested to have existed beneath sealing benthic microbial mats, even in the presence of oxic bottom waters (Gehling, 1991; Gehling, 1999; Dzik, 2003; Gehling et al., 2005; Mapstone \& Mcllroy, 2006). The pyrite 'sole veneers' can either be observed directly (Fig. 3, Fedonkin \& Waggoner, 1997; Dzik, 2003), where sulphur isotopes support the role of sulphate reduction (Fig. 1, Steiner \& Reitner, 2001) or they can be inferred by tracing the diagenetic pathway from pyrite to haematite or limonite (see Mapstone \& Mcllroy, 2006). Although the precipitation of pyrite at shallow depths (1-2cm) beneath an event bed has been identified as a difficulty with this model (e.g. Retallack, 2007), the predictions of the Mixed Layer Model appear able to account for this, without necessarily requiring benthic microbial mats (see also Bailey et al., 2006).

Despite the elegance of this model (e.g. Gehling, 1991; 1999; Gehling et al., 2005), a number of observations still need to be addressed. First, we emphasize that Ediacaran petalonamaean fossils are known to occur without obvious evidence for associated microbial biofilms, although it is clear that they may simply not be preserved. Importantly, field and petrographic investigations in many localities studied by us show that pyrite veneers or even its weathering products can be absent. To this we would add the paradox that both microbial mats and suitable event beds have continued to exist throughout the Phanerozoic without associated macrofossil preservation, although it arguably persisted into the late Cambrian (e.g. Hagadorn et al., 2002). While rapid authigenic lithification of the overlying sediment may have been an important factor in 
petalonamaean preservation, the roles of diagenetic pyrite and microbial mats appear to be more open to question. The Mixed Layer Model suggests that while microbial mats may often have played an important role, they may not have been 'necessary preconditions' for Ediacaran macrofossil preservation, as originally suggested by Gehling (1999).

Another model considers the rapid lithification of overlying ash layers as the key factor in the preservation of fossils as negative moulds on bedding plane top surfaces, for example at Mistaken Point in Newfoundland and in Charnwood Forest, UK ('Conceptionstyle' of Narbonne, 2005). This explanation does not obviously explain the formation of negative moulds within mudstones that lack ash layers, as in the Longmynd. Nor does it explain the preservation of fossils beneath distal turbidites, as in Charnwood Forest. Here again, there is also another uniformitarian difficulty: ash layers are common throughout the Phanerozoic record but these ashes are usually without comparable soft-tissue preservation (but see Orr et al., 2000). This therefore raises the possibility that the relatively rapid cohesion of the sediment owing to microbial mat stablilization or authigenic (silicate) cementation may have been more important than ash layers in this style of preservation (Pflug 1972; Narbonne, 2005).

Finally, attention is drawn to the preservation of fossils in three-dimensions within sedimentary beds (Fig. 3C, 'Nama-style' of Narbonne, 2005) from many Ediacaran localities (e.g. Glaessner \& Wade, 1966; Hagadorn \& Waggoner, 2000; Dzik, 2003; Grazhdankin, 2004 Narbonne, 2004), which has remained difficult to explain because the obvious agents for replication or cementation are as yet undeciphered (but see Waggoner, 1995; Pflüger \& Gresse, 1996; Gehling, 1999). It is known from younger, Lower Cambrian (Dzik \& Krumbiegel, 1989) and Ordovician quartzites (Samuelsson et al., 2001) as well from plants in Jurassic fluvial sandstones (van Konijnenburg-van Cittert, 2008). But such preservation is comparatively rare in the Phanerozoic, in spite of the availability of apparently suitable substrates. The preservation of delicate structures in this mode appears to necessitate the rapid lithification of surrounding sediments, prior to significant decay. Observations of iron-stained fossils from the Nama group could be used to argue for a role of diagenetic pyrite (i.e. 'death mask', Gehling, 1999), although obvious evidence for diagenetic pyrite is lacking at other localities showing 'within-bed' preservation, including the Conception Group of Newfoundland (Narbonne et al., 2004) and in the White Sea region of Russia.

\section{Conclusion}

The Mixed Layer Model outlined here may provide some assistance in explaining the wide range of styles of fossil preservation found in the Ediacaran, including the preservation of microbial mats and macrofossils across a variety of siliciclastic settings. Firstly, it implies that anaerobic heterotrophic microbial zones, such as the sulphate reduction zone, typically existed at much shallower depths during the Ediacaran Period than at later times. This may help to account for the preponderance of diagenetic pyrite, which is interpreted to have formed on the sediment surface, or during very shallow burial $(1-2 \mathrm{~cm})$ in shallow water environments during the Ediacaran Period (Gehling, 1999; Gehling et al., 2005; Mapstone \& Mcl Iroy, 2006). This also supports the formation of a pyrite veneer at shallow sediment depths, beneath oxidized bottom-waters, without necessitating the existence of benthic microbial mats (Gehling, 1991; 1999; Gehling et al., 2005).

In many cases, however, there seems to be limited evidence for primary pyrite veneers in association with Ediacaran macrofossils: notably in bedding planes studied both in the field and petrographically from the Mistaken Point and Trepassey Formations of Newfoundland; bedding planes from the Longmyndian Supergroup of England; and in the specimens studied from the Nama Group of Namibia (Fig. 7). The Mixed Layer Model may be able to assist here, because one of its predictions is that of high silicate ion concentrations at shallow depths within the sediment profile, thereby raising the 
possibility that authigenic silicate (e.g. phyllosilicate) precipitation could have played a much more important role within the upper layer of sediments during early diagenesis than it does today (see Pflug 1972; Gehling, 1999; Mapstone \& Mcllroy, 2006). The precipitation of silicate cements prior to, or during microbial degradation of carbonaceous materials represents a potentially important and little recognized agent of sediment lithification (e.g. Ferris et al., 1987; 1988; McMahon et al., 1992; Konhauser \& Urrutia, 1999). Silicate precipitation may therefore help to explain some of the more paradoxical examples of Ediacaran fossil preservation and, as suggested by Pflug (1972), may be a more important factor in Ediacaran macrofossil preservation, than is currently appreciated.

These predictions need to be tested by further investigations of the Ediacaran sedimentary and fossil records. In particular, further discoveries of early diagenetic silicate mineral cements will be of great importance for the testing of this model (Fig. 4-5, see Mapstone \& Mcllroy, 2006). Particular difficulties associated with the investigation of ancient clay mineral cements include determination of the relative rates and timing of silicate precipitation, and tracing the diagenesis of these diagenetic minerals through meso- and telodiagenesis (e.g. Mapstone \& Mcllroy 2006).

Features which might be expected to occur in the Ediacaran Period include the widespread permineralization of microbial filaments by silicate, pyrite and phosphate minerals; evidence for sedimentary pyrite and phosphate formed close to the sedimentwater interface; and evidence for an unusual cohesiveness and firmness of shallow marine sediments. Possible indicators for the later may include observations such as synsedimentary microfaults cutting fossiliferous surfaces (Fig. 3A, Gehling, 1999; Dzik, 2003; Gehling et al., 2005; Droser et al., 2006), open or 'floating' trace fossils with sharp margins (e.g. Droser et al., 2002a; 2002b; Jensen et al., 2005) and subaqueous shrinkage (Fig. 3A) or compaction cracks (cf. 'Manchuriophycus'; Seilacher, 2007). Observations which could prove to be problematic for the model might include widespread evidence for the ready resuspension of shallow-water sediment particles, or evidence for extensive, deep, soft, 'soupy' substrates. Complimentary geochemical investigations also need to be undertaken to attempt to identify and characterize microbial heterotrophic zones at shallow depths within Ediacaran sedimentary sequences.

While the Mixed Layer Model may help to understand some of the more unusual taphonomic processes in the Ediacaran Period, it is merely one tool among many for investigations into the palaeobiology and palaeoecology of this interval. It is hoped that an improved understanding of the evolution of preservational processes will be of benefit in future researches into problems such as the chemical composition of Ediacaran tissues, taphonomic biases caused by decay processes, and taphonomic biases between different Ediacaran assemblages.

\section{Acknowledgements}

The authors thank Duncan Mcllroy and Alex Liu for their discussions, help, comments and field support, the National Trust for access to Longmyndian localities, and the staff of the British Geological Survey Palaeontology unit and the Oxford University Museum of Natural History for their assistance with access to materials. The comments and suggestions of two anonymous reviewers and Nora Noffke significantly improved the manuscript. 


\section{References}

Alessandrello, A., Bracchi, G., 2003. Eldonia berbera n. sp., a new species of the enigmatic genus Eldonia Walcott, 1911 from the Rawtheyan (Upper Ordovician) of Anti-Atlas (Erfoud, Tafilalt, Morocco). Atti della Società italiana de Scienze naturali e del Museo Civico di Storia naturale di Milano 144(2), 337-358.

Aller, R.C., 1978. Experimental studies of changes produced by deposit feeders on pore water, sediment and overlying water chemistry. American J ournal of Science 278, 1185-1234.

Aller, R.C., 1982. The effects of macrobenthos on chemical properties of marine sediments and overlying water. In: McCall, P.L., Tevesz, M.J.S., (Eds.), Animal-sediment relations. Plenum, New York, pp. 53-102.

Aller, R.C., 1984. The importance of relict burrow structure and burrow irrigation in controlling sedimentary solute distributions. Geochimica et Cosmochimica Acta 48, 1929-1934.

Aller, R.C., 1994. Bioturbation and remineralization of sedimentary organic matter: Effects of redox oscillations. Chemical Geology 114, 331-345.

Allison, L.E., 1947. Effects of microorganisms on permeability of soils under prolonged submergence. Soil Science 63, 439-450.

Allison, P.A., 1988. Konservat-lagerstätten: cause and classification. Paleobiology 14(4), 331-344.

Allison, P.A., Briggs, D.E.G., 1991. The taphonomy of non-mineralized tissues. In: Allison, P.A., Briggs, D.E.G., (Eds.), Taphonomy: Releasing the data locked in the fossil record. Plenum Press, New York, pp. 25-70.

Allison, P.A., Briggs, D.E.G., 1993. Exceptional fossil record: Distribution of soft-tissue preservation through the Phanerozoic. Geology 21, 527-530.

Antcliffe, J.B., Brasier, M.D., 2007. Charnia and sea pens are poles apart. Journal of the Geological Society, London 164(1), 49-51.

Awramik, S.M., 1971. Precambrian columnar stromatolite diversity: reflection of metzoan appearance. Science 174, 825-827.

Bailey, J.V., Corsetti, F.A., Bottjer, D.J., Marenco, K.N., 2006. Microbially-mediated environmental influences on metazoan colonization of matground ecosystems: evidence from the Lower Cambrian Harkless Formation. Palaios 21(3), 215-226.

Barghoorn, E.S., Schopf, J.W., 1965. Microorganisms from the late Precambrian of central Australia. Science 150, 337-339.

Barth, H.-J., 2003. The influence of cyanobacteria on oil polluted intertidal soils at the Saudi Arabian Gulf shores. Marine Pollution Bulletin 46(10), 1245-1252.

Bell, C.M., Angseesing, J.P.A., Townsend, M.J., 2001. A Chondrophorine (Medusoid Hydrozoan) from the Lower Cretaceous of Chile. Palaeontology 44(5), 1011-1023.

Bengtson, S., 2004. Early skeletal fossils. Paleontological Society Papers 10, 67-77.

Berner, R.A., 1969. Migration of iron and sulfur within anaerobic sediments during early diagenesis. American Journal of Science 267, 19-42.

Berner, R.A., 1970. Sedimentary pyrite formation. American Journal of Science 268, 1-23.

Berner, R.A., 1985. Sulphate reduction, organic matter decomposition and pyrite formation. Philosophical Transactions of the Royal Society, A 315, 25-37.

Bottjer, D.J., Hagadorn, J.W., Dornbos, S.Q., 2000. The Cambrian substrate revolution. GSA Today 10(9), 1-7.

Boudreau, B.P., 1994. Is burial velocity a master parameter for bioturbation. Geochimica et Cosmochimica Acta 58(4), 1243-1249.

Brasier, M.D., 1979. The Cambrian Radiation Event. In: House, M.R. (Ed.), Origin of Major Invertebrate Groups. Academic Press, London, pp. 103-159.

Brasier, M.D., 1992. Palaeoceanography and changes in the biological cycling of phosphorus across the Precambrian-Cambrian boundary. In: Lipps, J.H., Signor, P.W., (Eds.), Origin and early evolution of the Metazoa. Plenum Press, New York, pp. 483-523.

Brasier, M. D., Antcliffe, J. B., 2004. Decoding the Ediacaran Enigma. Science 305, 1115-1117.

Brasier, M.D., Callow, R.H.T., 2007. Changes in the patterns of phosphatic preservation across the Proterozoic-Cambrian transition. Memoirs of the Association of Australasian Palaeontologists 34, 377-389.

Brasier, M.D., Ancliffe, J.B., 2009. A fresh look at the supposed bilaterian Dickinsonia from the Ediacara Hills. Palaeogeography, Palaeoclimatology, Palaeoecology 270, 311-323.

Brasier, M.D., Cowie, J., Taylor, M., 1994. Decision on the Precambrian-Cambrian boundary. Episodes 17, 3-8. 
Brasier, M.D., Antcliffe, J.B., Callow, R.H.T., Evolutionary trends in remarkable preservation across the Ediacaran-Cambrian transition: the impact of metazoan mixing. In: Allison, P.A., Bottjer, D.J., (Eds.), Taphonomy: Process and bias through time. Elsevier, In Press a.

Brasier, M.D., Callow, R.H.T., Menon, L.R., Liu, A.G., Osmotrophic biofilms: from modern to ancient. In Press $b$.

Bromley, R., 1996. Trace fossils: biology, taphonomy and applications. Chapman \& Hall, London, $361 p$.

Bowring, S.A., Myrow, P., Landing, E., Ramenzani, J., 2003. Geochronological constraints on terminal Neoproterozoic events and the rise of metazoans. NASA Astrobiology Institute General Meeting, 113-114.

Burdige, D.J., 2006. Geochemistry of marine sediments. Princeton University Press, Princeton, 630p.

Butterfield, N.J., 1997. Plankton ecology and the Proterozoic-Phanerozoic transition. Paleobiology 23(2), 247-262.

Butterfield, N.J., 2003. Exceptional fossil preservation and the Cambrian explosion. Integrative and Comparative Biology 43, 166-177.

Callow, R.H.T., Brasier, M.D., 2009. A solution to Darwin's dilemma of 1859: exceptional preservation in Salter's material from the late Ediacaran Longmyndian Supergroup, England. Journal of the Geological Society, London 166(1), 1-4.

Canfield, D.E., Raiswell, R., 1991. Pyrite formation and fossil preservation. In: Allison, P.A., Briggs, D.E.G., (Eds.), Taphonomy: Releasing the data locked in the fossil record. Plenum Press, New York, pp. 337-387.

Carney, J.N., 2000. Chapter 2: Charnwood Forest, Introduction. In: J.N. Carney, J.M. Horak, T.C. Pharaoh, W. Gibbons, D. Wilson, W.J. Barclay, R.E. Bevins, J.C.W. Cope, T.D. Ford (Eds.), Precambrian rocks of England and Wales, Geological Conservation Review Series No. 20. Joint Nature Conservation Committee, Peterborough, pp. 21-25.

Chafetz, H.S., Buczynski, C., 1992. Bacterially induced lithification of microbial mats. Palaios 7, 277293.

Cohen, P.A., Bradley, A., Knoll, A.H., Grotzinger, J.P., Jensen, S., Abelson, J., Hand, K., Love, G., Metz, J., McLoughlin, N., Meister, P., Shepard, R., Tice, M., Wilson, J., 2009. Tubular compression fossils from the Ediacaran Nama Group, Namibia. Journal of Paleontology 83(1), 110-122.

Conway-Morris, S., Grazhdankin, D., 2005. Enigmatic worm-like organisms from the Upper Devonian of New York: An apparent example of Ediacaran-like preservation. Palaeontology 48(2), 395410.

Compston, W., Wright, A.E., Toghill, P., 2002. Dating the Late Precambrian volcanicity of England and Wales. Journal of the Geological Society, London 159, 323-339.

Crimes, T.P., 1992. Changes in the trace fossil biota across the Proterozoic-Phanerozoic boundary. J ournal of the Geological Society, London 149, 637-646.

Crimes, T.P., Mcllroy, D., 1999. A biota of Ediacaran aspect from Lower Cambrian strata on the Digermul Peninsular, Arctic Norway. Geological Magazine 36(6), 633-642.

Crimes, T.P., Insole, A., Williams, B.J.P., 1995. A rigid-bodied Ediacaran biota from Upper Cambrian strata in County Wexford, Eire. Geological J ournal 30, 89-109.

Donovan, S.K., Lewis, D.N., 2001. Fossils explained 35: The Ediacaran biota. Geology Today 17(3), 115-120.

Dornbos, S.Q., Bottjer, D.J., 2000. Evolutionary paleoecology of the earliest echinoderms: Helicoplacoids and the Cambrian substrate revolution. Geology 28(9), 839-842.

Dornbos, S.Q., Bottjer, D.J., Chen, J.-Y., 2004. Evidence for seafloor microbial mats and associated metazoan lifestyles in Lower Cambrian phosphorites of Southwest China. Lethaia 37, 127-137.

Dornbos, S.Q., Bottjer, D.J., Chen, J.-Y., 2005. Paleoecology of benthic metazoans in the Early Cambrian Maotianshan Shale biota and the Middle Cambrian Burgess Shale biota: evidence for the Cambrian substrate revolution. Palaeogeography, Palaeoclimatology, Palaeoecology 220, 47-67.

Droser, M.J., Bottjer, D.J., 1988. Trends in depth and extent of bioturbation in Cambrian carbonate marine environments, western United States. Geology 16(3), 233-236.

Droser, M.J., Gehling, J.G., Jensen, S.R., 1999. When the worm turned: concordance of Early Cambrian ichnofabric and trace-fossil record in siliciclastic rocks of South Australia. Geology 27(7), 625-628.

Droser, M.J., Jensen, S.R., Gehling, J.G., 2002a. Trace fossils and substrates of the terminal Proterozoic-Cambrian transition: Implications for the record of early bilaterians and sediment mixing. Proceedings of the National Academy of Sciences, USA 99, 12572-12576. 
Droser, M.J., Jensen, S., Gehling, J.G., Myrow, P.M., Narbonne, G.M., 2002b. Lowermost Cambrian ichnofabrics from the Chapel Island Formation, Newfoundland: Implications for Cambrian substrates. Palaios 17, 3-15.

Droser, M.J., Jensen, S., Gehling, J.G., 2004. Development of early Cambrian ichnofabrics: evidence from shallow marine siliciclastics. In: Mcllroy, D., (Ed.), The application of ichnology to palaeoenvironmental and stratigraphic analysis. Geological Society, London, Special Publication 228, pp. 383-396.

Droser, M.J., Gehling, J.G., Jensen, S.R., 2006. Assemblage palaeoecology of the Ediacara Biota: The unabridged edition. Palaeogeography, Palaeoclimatology, Palaeoecology 232, 131-147.

Dzik, J., 2003. Anatomical information content in the Ediacaran fossils and their possible zoological affinities. Integrative and Comparative Biology 43(1), 114-126.

Dzik, J., Krumbiegel, G., 1989. The oldest "onychophoran" Xenusion: A link between phyla? Lethaia 22(2), 169-181.

Fedonkin, M.A., 1992. Vendian faunas and the early evolution of Metazoa. In: Lipps, J.H., Signor, P.W., (Eds.), Origin and early evolution of the Metazoa. Plenum Press, New York, pp. 87-129.

Fedonkin, M.A., Waggoner, B.M., 1997. The late Precambrian fossil Kimberella is a mollusc-like organism. Nature 388, 868-871.

Ferris, F.G., Fyfe, W.S., Beveridge, T.J., 1987. Bacteria as nucleation sites for authigenic minerals in a metal-contaminated lake sediment. Chemical Geology 63, 225-232.

Ferris, F.G., Fyfe, W.S., Beveridge, T.J., 1988. Metallic ion binding by Bacillus substilis: Implications for fossilization of microorganisms. Geology 16, 149-152.

Ford, T.D., 1958. Precambrian fossils from Charnwood Forest. Yorkshire Geological Society Proceedings 31, 211-217.

Gabbott, S.E., Hou, X.G., Norry, N.J., Siveter, D.J., 2001. Preservation of fossils in clay minerals; a unique example from the Upper Ordovician Soom Shale of South Africa. Proceedings of the Yorkshire Geological Society 53, 237-244.

Gehling, J.G., 1991. The case for Ediacaran fossil roots to the metazoan tree. Geological Society of India Memoir 20, 181-224.

Gehling, J.G., 1999. Microbial mats in terminal Proterozoic siliciclastics: Ediacaran death masks. Palaios 14, 40-57.

Gehling, J.G., 2000. Environmental interpretation and a sequence stratigraphic framework for the terminal Proterozoic Ediacara Member within the Rawnsley Quartzite, South Australia. Precambrian Research 100, 65-95.

Gehling, J. G., Droser, M. L., Jensen, S. R., Runnegar, B. N., 2005. Ediacara Organisms: Relating Form to Function. In: Briggs, D.E.G., (Ed.), Evolving form and function: fossils and development. Peabody Museum of Natural History, New Haven, pp. 43-66.

Gerdes, G., Klenke, T., Noffke, N., 2000. Microbial signatures in peritidal siliciclastic sediments: a catalogue. Sedimentology 47, 279-308.

Glaessner, M.F., 1984. The dawn of animal life: A biohistorical study. Cambridge University Press, Cambridge, $244 \mathrm{pp}$.

Glaessner, M. F., Wade, M., 1966. The late Precambrian fossils from Ediacara, South Australia. Palaeontology 9(4), 599-628.

Glaizer, A.N., Nikaido, H., 1995. Microbial technology: Fundamentals of applied microbiology. W.H. Freeman \& Co., New York, 662p.

Grazhdankin, D., 2004. Patterns of distributions in the Ediacaran biotas: facies versus biogeography and evolution. Paleobiology 30(2), 203-221.

Grazhdankin, D., Balthasar, U., Nagovitsin, K.E., Kochnev, B.B., 2008. Carbonate-hosted Avalontype fossils in arctic Siberia. Geology 36(10), 803-806.

Grazhdankin, D., Gerdes, G., 2007. Ediacaran microbial colonies. Lethaia 40, 201-210.

Grotzinger, J.P., Watters, W.A., Knoll, A.H., 2000. Calcified metazoans in thrombolite-stromatolite reefs of the terminal Neoproterozoic Nama Group, Namibia. Palaeobiology 26(3), 334-359.

Hagadorn, J.W., Bottjer, D.J., 1997. Wrinkle structures: Microbially mediated sedimentary structures common in subtidal siliciclastic settings at the Proterozoic-Phanerozoic transition. Geology 25(11), 1047-1050.

Hagadorn, J.W., Bottjer, D.J., 1999. Restriction of a late Neoproterozoic biotope: Suspect-microbial structures and trace fossils at the Vendian-Cambrian transition. Palaios 14, 73-85.

Hagadorn, J.W., Waggoner, B., 2000. Ediacaran fossils from the southwestern Great Basin, United States. J ournal of Paleontology 74(2), 349-359.

Hagadorn, J.W., Fedo, C.M., Waggoner, B.M., 2000. Early Cambrian Ediacaran-type fossils from California. J ournal of Paleontology 74(4), 731-740. 
Hagadorn, J.W., Dott, R.H., J r., Damrow, D., 2002. Stranded on a Late Cambrian shoreline: medusae from central Wisconsin. Geology 30(2), 147-150.

Jenkins, R.J., McKirdy, D.M., Foster, C.B., O'Leary, T., Pell, S.D., 1992. The record and stratigraphic implications of organic walled microfossils from the Ediacaran (terminal Proterozoic of South Australia). Geological Magazine 129, 401-410.

Jensen, S., 2003. The Proterozoic and earliest Cambrian trace fossil record; patterns, problems and perspectives. Integrative and Comparative Biology 43(1), 219-228.

Jensen, S., Droser, M.L., Gehling, J.G., 2005. Trace fossil preservation and the early evolution of animals. Palaeogeography, Palaeoclimatology, Palaeoecology 220, 19-29.

Jones, J.G., 1985. Microbes and microbial processes within sediments. Philosophical Transactions of the Royal Society, A 315, 3-17.

Knoll, A.H., 1985. Exceptional preservation of photosynthetic organisms in silicified carbonates and silicified peats. Philosophical Transactions of the Royal Society, B 311, 111-122.

Konhauser, K.O., Urrutia, M.M., 1999. Bacterial clay authigenesis: a common biogeochemical process. Chemical Geology 161, 399-413.

Krumbein, W.E., Brehm, U., Gerdes, G., Gorbushina, A.A., Levit, G., Palinska, K.A., 2003. Biofilm, biodictyon, oolites, stromatolites geophysiology, global mechanism, parahistology. In: Krumbein, W.E., Paterson, D.M., Zavarzin, G.A., (Eds.), Fossil and recent biofilms: a natural history of life on Earth. Kluwer Academic, Dordrecht, pp. 1-27.

Levit, G.S., Krumbein, W.E., 2003. Is there an adequate terminology of biofilms and microbial mats? In: Krumbein, W.E., Paterson, D.M., Zavarzin, G.A., (Eds.), Fossil and recent biofilms: a natural history of life on Earth. Kluwer Academic, Dordrecht, pp. 333-341.

Logan, G.A., Hayes, J.M., Hieshima, G.B., Summons, R.E., 1995. Terminal Proterozoic reorganization of biogeochemical cycles. Nature 376, 53-56.

Maliva, R.G., Knoll, A.H., Siever, R., 1989. Secular change in chert distribution: a reflection of evolving biological participation in the silica cycle. Palaios 4, 519-532.

Maliva, R.G., Knoll, A.H., Simonson, B.M., 2005. Secular change in the Precambrian silica cycle: insights from chert petrology. Geological Society of America Bulletin 117, 835-845.

Mapstone, N.B., Mcllroy, D., 2006. Ediacaran fossil preservation: taphonomy and diagenesis of a discoid biota from the Amadeus Basin, Central Australia. Precambrian Research 149, 126-148.

Martin, M.W., Grazhdankin, D.V., Bowring, S.A., Evans, D.A.D., Fedonkin, M.A., Kirschvink, J.L., 2000. Age of Neoproterozoic bilaterian body and trace fossils, White Sea, Russia: Implications for metazoan evolution. Science 288, 841-845.

Martin, W.R., Sayles, F.L., 2003. The recycling of biogenic material at the seafloor. Treatise on Geochemistry 7, 27-65.

Mcllroy, D., \& Walter, M.R., 1997. A reconsideration of the biogenicity of Arumberia banksi Glaessner and Walter. Alcheringa 21, 79-80.

Mcllroy, D., Logan, G.A., 1999. The impact of bioturbation on infaunal ecology and evolution during the Proterozoic-Cambrian transition. Palaios 14, 58-72.

Mcllroy, D., Crimes, T.P., Pauley, J.C., 2005. Fossils and matgrounds from the Neoproterozoic Longmyndian Supergroup, Shropshire, UK. Geological Magazine 142(4), 441-455.

McLoughlin, N., Wilson, L.A., Brasier, M.D., 2008. Growth of synthetic stromatolites and wrinkle structures in the absence of microbes - implications for the early fossil record. Geobiology 6(2), 95-105.

McMahon, P.B, Chapelle, F.H., Falls, W.F., Bradley, P.M., 1992. Role of microbial processes in linking sandstone diagenesis with organic-rich clays. Journal of Sedimentary Petrology 62, 1-10.

Misra, S.B., 1971. Stratigraphy and depositional history of late Precambrian coelenterate- bearing rocks, southeastern Newfoundland. Geological Society of America Bulletin 82, 979-988.

Narbonne, G., M., 2004. Modular construction in the Ediacara biota. Science 315, 1141-1144.

Narbonne, G., M., 2005. The Ediacara Biota: Neoproterozoic origin of animals and their ecosystems. Annual Review of Earth and Planetary Sciences 33, 421-442.

Narbonne, G.M., 2007. Canadian paleontology conference: Field trip guidebook No. 11. CPC 2007, St Johns. Geological Association of Canada - Paleontology Division, 37 pp.

Narbonne, G.M., Gehling, J.G., 2003. Life after snowball; the oldest complex Ediacaran fossils. Geology 31(1), 27-30.

Narbonne, G.M., Saylor, B.Z., Grotzinger, J.P., 1997. The youngest Ediacaran fossils from Southern Africa. J ournal of Paleontology 71, 953-967.

Narbonne, G.M., Dalrymple, R.W., La Flamme, M., Gehling, J.G., Boyce, W.D., 2005. Life after snowball: Mistaken Point biota and the Cambrian of Avalon. North American Paleontological Convention field trip guidebook. NAPC, $98 \mathrm{pp}$. 
Noffke, N., 2000. Extensive microbial mats and their influences on the erosional and depositional dynamics of a siliciclastic cold water environment (Lower Arenigian, Montagne Noire, France). Sedimentary Geology 136, 207-215.

Noffke, N., 2007. Microbially induced sedimentary structures in Archean Sandstones: a new window into early life. Gondwana Research 11, 336-342.

Noffke, N., 2009. The criteria for the biogenicity of microbially induced sedimentary structures (MISS) in Archean and younger, sandy deposits. Earth-Science Reviews - this volume.

Noffke, N., Gerdes, G., Klenke, T., Krumbein, W.E., 2001. Microbially induced sedimentary structures - a new category within the classification of primary sedimentary structures. J ournal of Sedimentary Research 71(6), 649-656.

Noffke, N., Knoll, A.H., Grotzinger, J.P., 2002. Sedimentary controls on the preservation of microbial mats in siliciclastic deposits: A case study from the Upper Neoproterozoic Nama Group, Namibia. Palaios 17(6), 533-544.

Noffke, N., Hazen, R., Nhleko, N., 2003. Earth's oldest microbial mat in a siliciclastic marine environment (2.9 Ga Mozaan Group, South Africa. Geology 31(8), 673-676.

Noffke, N., Beukes, N., Gutzmer, J., Hazen, R., 2006a. Spatial and temporal distribution of microbially induced sedimentary structures: a case study from siliciclastic storm deposits of the 2.9 Ga Witwatersrand Supergroup, South Africa. Precambrian Research 146, 35-44.

Noffke, N., Eriksson, K.A., Hazen, R.M., Simpson, E.L., 2006b. A new window into Archean life: microbial mats in Earth's oldest siliciclastic tidal deposits (3.2 Ga Moodies Group, South Africa). Geology 34(4), 253-256.

Noffke, N., Beukes, N., Bower, D., Hazen, R.M., Swift, D.J.P., 2008. An actualistic perspective into Archean worlds - (cyano-)bacterially induced sedimentary structures in the siliciclastic Nhlazatse Section, 2.9 Ga Pongola Supergroup, South Africa. Geobiology 6, 5-20.

Orr, P.J., Briggs, D.E.G., Sieveter, D.J., Siveter, D.J ., 2000. Three-dimensional preservation of a non-biomineralized arthropod in concretions in Silurian volcaniclastic rocks from Herefordshire, England. J ournal of the Geological Society, London 157, 173-186.

Orr, P.J., Benton, M.J., Briggs, D.E.G., 2003. Post-Cambrian closure of the deep-water slope-basin taphonomic window. Geology 31(9), 769-772.

Peat, C., 1984. Precambrian microfossils from the Longmyndian of Shropshire. Proceedings of the Geologists' Association 5, 17-22.

Perry, E.C., Lefticariu, L., 2003. Formation and geochemistry of Precambrian cherts. Treatise on Geochemistry 7, 99-113.

Peterson, K.J., Waggoner, B., Hagadorn, J.W., 2003. A fungal analog for Newfoundland Ediacaran fossils? Integrative and Comparative Biology 43, 127-136.

Pflug, H.D., 1972. Systematik der jung-präkambrischen Petalonamae. Paläontologische Zeitschrift 46, 56-67. (In German)

Pflüger, F., 1999. Matground structures and redox facies. Palaios 14, 25-39.

Pflüger, F., Gresse, P.G., 1996. Microbial sand chips - a non-actualistic sedimentary structure. Sedimentary Geology 102, 263-274.

Porter, S.M., Knoll, A.H., 2000. Testate amoebae in the Neoproterozoic era: evidence from vaseshaped microfossils in the Chuar Group, Grand Canyon. Paleobiology 26, 360-385.

Retallack, G.J., 1994. Were the Ediacaran fossils lichens? Paleobiology 20(4), 523-544.

Retallack, G.J., 2007. Growth, decay and burial compaction of Dickinsonia: an iconic Ediacaran fossil. Alcheringa 31(3), 315-340.

Rhoads, D.C., 1970. Mass properties, stability and ecology of marine muds and related burrowing activity. In: Crimes, T.P., Harper, J.D., (Eds.), Trace Fossils. Geological J ournal Special Issue 3. Liverpool Letterpress, pp. 391-406.

Rigby, S., Milsom, C.V., 2000. Origin, evolution and diversification of zooplankton. Annual Review of Ecology and Systematics 31, 293-313.

Runnegar, B., 1982. Oxygen requirements, biology and phylogenetic significance of the late Precambrian worm Dickinsonia, and the evolution of the burrowing habit. Alcheringa 6, 223239.

Ruttenberg, K.C., 2003. The global phosphorous cycle. Treatise on Geochemistry 8, 585-643.

Salter, J.W., 1856. On fossil remains in the Cambrian rocks of the Longmynd and North Wales. Quarterly Journal of the Geological Society 12, 246-251.

Salter, J.W., 1857. On annelide burrows and surface markings from the Cambrian rocks of the Longmynd. Quarterly J ournal of the Geological Society 13, 199-207.

Samuelsson, J., Butterfield, N.J., 2001. Neoproterozoic fossils from the Franklin Mountains, northwestern Canada: Stratigraphic and palaeobiological implications. Precambrian Research 
107, 235-251.

Samuelsson, J., Van Roy, P., Vecoli, M., 2001. Micropalaeontology of a Moroccan Ordovician deposit yielding soft-bodied organisms showing Ediacara-like preservation. Geobios 34(4), 365-373.

Savrda, C.E., Bottjer, D.J., 1989. Trace-fossil model for reconstructing oxygenation histories of ancient marine bottom waters: application to Upper Cretaceous Niobrara Formation, Colorado. Palaeogeography, Palaeoclimatology, Palaeoecology 74, 49-74.

Saylor, B.Z., Grotzinger, J.P., Germs, G.J.B., 1995. Sequence stratigraphy and sedimentology of the Neoproterozoic Kuibis and Schwarzrand Subgroups (Nama Group), southwest Namibia. Precambrian Research 73, 153-171.

Schieber, J., 1999. Microbial mats in terrigenous clastics: the challenge of identification in the rock record. Palaios 14, 3-12.

Schieber, J., 2007. Microbial mats on muddy substrates. In: Schieber, J., Bose, P.K., Eriksson, P.G., Banerjee, S., Sarkar, S., Altermann, W., Catuneanu, O., (Eds.), Atlas of microbial mat features preserved within the siliciclastic rock record. Atlases in Geoscience, 2. Elsevier, Amsterdam, pp. 117-133.

Schieber, J., Bose, P.K., Eriksson, P.G., Banerjee, S., Sarkar, S., Altermann, W., Catuneanu, O., (Eds.), 2007. Atlas of microbial mat features preserved within the siliciclastic rock record. Atlases in Geoscience, 2. Elsevier, Amsterdam, $311 \mathrm{pp}$.

Seilacher, A., 1956. Der Beginn des Kambriums als biologische Wende. Neues Jahrbuch für Geologie und Paläontologie Abhandlungen 103, 155-180.

Seilacher, A., 1984. Late Precambrian and early Cambrian Metazoa: Preservational or real extinctions. In: Holland, H.D., Trendall, A.F., (Eds.), Patterns of change in Earth evolution. Springer-Verlag, Berlin, pp. 159-168.

Seilacher, A., 1989. Vendozoa: Organismic construction in the Proterozoic biosphere. Lethaia 22(3), 229-239.

Seilacher, A., 1992. Vendobionta and Psammocorallia: lost constructions of Precambrian evolution. J ournal of the Geological Society, London 149, 607-613.

Seilacher, A., 1999. Biomat-related lifestyles in the Precambrian. Palaios 14, 86-93.

Seilacher, A., 2007. Trace fossil analysis. Springer, Berlin, $240 \mathrm{pp}$.

Seilacher, A., Pflüger, F., 1994. From biomats to benthic agriculture: a biohistoric revolution. In: Krumbein, W.E., Paterson, D.M., Stal, L., (Eds.), Biostabilization of Sediments. Bibliotheks und Informations system der Universität Oldenburg. Oldenburg, Germany, pp. 97-105.

Seilacher, A., Reif, W.-E., Westphal, F., 1985. Sedimentological, ecological and temporal patterns of fossil lagerstätten. Philosophical Transactions of the Royal Society of London, B 311, 5-23.

Seilacher, A., Grazhdankin, D., Leguta, A., 2003. Ediacaran biota: the dawn of animal life in the shadow of giant protists. Paleontological Research 7, 43-54.

Seilacher, A., Buatois, L.A., Mángano, M.G., 2005. Trace fossils in the Ediacaran-Cambrian transition: Behavioural diversification, ecological turnover and environmental shift. Palaeogeography, Palaeoecology, Palaeoclimatology 227, 323-356.

Shields, G.A., 2002. 'Molar-tooth microspar': a chemical explanation for its disappearance 750Ma. Terra Nova 14, 108-113.

Siever, R., 1992. The silica cycle in the Precambrian. Geochimica et Cosmochimica Acta 56(8), 3265-3272.

Steiner, M., Reitner, J., 2001. Evidence of organic structures in Ediacara-type fossils and associated microbial mats. Geology 29(12), 1119-1122.

van Konijnenburg-van Cittert, J.H.A., 2008. The Jurassic fossil plant record of the U.K area. Proceedings of the Geologists' Association 119, 59-73.

Wade, M., 1968. Preservation of soft-bodied animals in pre-Cambrian sandstones at Ediacara, South Australia. Lethaia 1(3), 238-267.

Waggoner, B.M., 1995. Ediacaran lichens: a critique. Comment and reply. Paleobiology 21, 393-397.

Wood, D.A., Dalrymple, R.W., Narbonne, G.M., Gehling, J.G., Clapham, M.E., 2003. Palaeoenvironmental analysis of the late Neoproterozoic Mistaken Point and Trepassey Formations, southeastern Newfoundland. Canadian J ournal of Earth Sciences 24, 440-458.

Worden, R.H., Morad, S., 2003. Clay minerals in sandstones: controls on formation, distribution and evolution. In: Worden, R.H., Morad, S., (Eds.), Clay mineral cements in sandstones. International Association of Sedimentologists Special Publication 34. Blackwell Publishing, Oxford, pp. 3-41.

Xiao, S., Shen, B., Zhou, C., Xie, G., Yuan, X., 2005. A uniquely preserved Ediacaran fossil with direct evidence for a quilted body plan. Proceedings of the National Academy of Sciences, USA 102, 10227-10232. 



\section{Figure Descriptions}

Figure 1. Diagram showing major changes in sediment processing and geochemistry from the Ediacaran (at left) to the Phanerozoic (at right), across the so-called 'agronomic' or 'substrate revolution'. This 'Mixed Layer Model' is based upon and formulated from a number of models, figures and ideas proposed and discussed previously (e.g. Seilacher \& Pflüger, 1994; Mcllroy \& Logan, 1999; Seilacher, 1999; Bottjer et al., 2000; Droser et al., 2002a; 2004; Bailey et al., 2006 and references in text). Here this model and attempts to expand the geochemical implications of these changes (especially Eh and $\mathrm{pH}$ ), in order to help us understand taphonomic processes across this interval. The almost total lack of burrowing, grazing and scavenging in the Ediacaran Period meant that sediment mixed layer was restricted to the extent of diffusion at the sediment-water interface. This may have been even further limited by the sealing effects of benthic microbial mats. Common sedimentary structures from this interval are shown and include 'old elephant skin' texture, pustulose markings, shrinkage cracks and carbonate crystal fans (see Gehling, 1999; Seilacher, 1999). The redox boundary (solid line) lay at shallow depths (e.g. Mcl Iroy \& Logan, 1999; Seilacher, 1999; Bottjer et al., 2000; Bailey et al., 2006) and this sharp, shallow (possibly only millimetres deep) redox boundary enabled high levels of ionic (e.g. silicate) saturation to develop near the sediment-water interface, facilitating rapid sediment lithification and moulding of organic remains (i.e. microbes and macrofossils). Important taphonomic windows for unmineralized tissues (e.g. pyritization Eq. 5 and phosphatization) are also found at relatively shallow depths. The increase in the density and depth of bioturbation at the Ediacaran-Cambrian transition pushed down the redox boundary and made it more diffuse, due to processes of diffusion, particle mixing and bioirrigation (Seilacher \& Pflüger, 1994; Bottjer et al., 2000; Burdige, 2006). This increased the extent of recycling of organic matter before it could reach suitable zones for fossilization, which are found at greater depths within the sediment. This also lowered the sediment $\mathrm{pH}$ at shallow depths (Eq. 3). In the Phanerozoic, this $\mathrm{pH}$ fall is, in part, buffered by the dissolution of carbonate biominerals (Eq. 4). In the Precambrian, the pH fall is buffered only by the release of alkalinity in microbial heterotrophic reactions. Zones of mineral saturation and hence lithification are encountered deeper within the sediment profile during the Phanerozoic and the preservation potential of organic materials is greatly reduced. Important reactions are broadly as follows:

(1) Oxygenic photosynthesis: $\mathrm{CO}_{2}+\mathrm{H}_{2} \mathrm{O} \leftrightarrow \mathrm{CH}_{2} \mathrm{O}+\mathrm{O}_{2}$ (Increases Eh and pH)

(2) Calcium carbonate precipitation: $\mathrm{Ca}^{2+}+2 \mathrm{HCO}_{3}^{-} \leftrightarrow \mathrm{CaCO}_{3}+\mathrm{CO}_{2}+\mathrm{H}_{2} \mathrm{O}$ (Requires high $\mathrm{pH}$ )

(3) Aerobic respiration (microbial and metazoan): $\mathrm{CH}_{2} \mathrm{O}+\mathrm{O}_{2} \leftrightarrow \mathrm{CO}_{2}+\mathrm{H}_{2} \mathrm{O}$ (Lowers pH and Eh)

(4) Calcium carbonate dissolution: $\mathrm{CaCO}_{3}+\mathrm{CO}_{2}+\mathrm{H}_{2} \mathrm{O} \leftrightarrow \mathrm{Ca}^{2+}+2 \mathrm{HCO}_{3}{ }^{-}$(Buffers $\mathrm{pH}$ fall)

(5) Sulphate reduction: $2 \mathrm{CH}_{2} \mathrm{O}+\mathrm{SO}_{4}{ }^{2-} \leftrightarrow \mathrm{HCO}_{3}{ }^{-}+\mathrm{HS}^{-}+\mathrm{CO}_{2}+2 \mathrm{H}_{2} \mathrm{O}$ (Can cause pyritization)

(6) Methanogenesis: $2 \mathrm{CH}_{2} \mathrm{O} \leftrightarrow \mathrm{CH}_{4}+\mathrm{CO}_{2}$ (Buffers $\mathrm{pH}$ and may lead to carbonate precipitation)

Figure 2. Typical bedding plane structures which are commonly used as evidence for ancient microbial mats in the Ediacaran Period. a: Lumpy and pustulose texture from a fossiliferous bedding plane in Charnwood Forest, Leicestershire, England. b: Large, irregular, sub-circular bedding plane feature, described as a 'bubble mat', from the ' $E$ ' surface at Mistaken Point, Newfoundland. c: Characteristic sediment bedding plane texture known as 'old elephant skin', which can be compared with structures found in association 
with modern microbial mats. From the c. 555Ma Rawnsley Quartzite, Flinders Ranges. d: Negative relief preservation of Dickinsonia costata from bedding plane sole in the c. 555 Ma Rawnsley Quartzite showing a typical wrinkly and lumpy surface texture. Shown as a reversed (difference cloud) image to show the appearance of the fossil and the surrounding seafloor before burial by sand. Note that the wrinkled and pustular texture not only surrounds, but also underlies the fossil, suggesting that the organism was extremely thin. Specimen from the Roland Goldring Collection, Oxford University Museum, OUM.ÁW.90. Scale bar $1 \mathrm{~cm}$ for (a) \& (d) and $5 \mathrm{~cm}$ for (b). Lens cap in (c) is c. $6 \mathrm{~cm}$ in diameter.

Figure 3. Dickinsonia costata from the c. 555 Ma White Sea Region, Russia preserved on a bedding plane sole, in association with pyrite and exceptionally preserved pyritized microbial filaments. a: Poorly preserved specimen of Dickinsonia from bedding plane sole, which is cut by numerous shrinkage cracks. Dark pyritic regions (arrowed) cover the fossil and sediment surface. b: Detail of pyritic region arrowed in (a) showing sub-parallel and entwined pyritized microbial filaments. Scale bar $1 \mathrm{~cm}$ for (a) and $1 \mathrm{~mm}$ for (b).

Figure 4. Microbial preservation in the Longmyndian Supergroup. a: Petrographic thin sections of shales from the c. $555 \mathrm{Ma}$ Lightspout Formation, showing parallel oriented carbonaceous filaments forming a laminated microbial mat fabric. OUM Á.2388. b: Densely packed, mat-building filaments preserved in white-coloured aluminosilicate minerals on bedding planes of the Burway Formation, Longmyndian Supergroup. c: Large permineralized microbial remains preserved in a white aluminosilicate mineral. D: Clusters of discoidal, microbial bedding plane markings, preserved in aluminosilicate mineral. Scale bar $1 \mathrm{~mm}$ for $(\mathrm{a}-\mathrm{b})$ and $(\mathrm{d}), 0.5 \mathrm{~mm}$ for $(c)$.

Figure 5. Microbial impressions and moulds preserved in high-relief on siliciclastic bedding planes. a: John Salter's original specimen from Yearling Hill, Church Stretton, Shropshire. From British Geological Survey Specimen BGS GSM 49157. The counterpart of this specimen was originally figured by Salter, (1857 pl. V, fig. 1) who described "rain-prints on rippled surface with Annelide-burrows (Arenicolites sparsus; young) in the hollows of the ripple", although these structures have since been reinterpreted (see Mcllroy et al., 2005). This specimen contains abundant narrow, sinuous negative relief impressions of microbial filaments, overlying gentle positive relief circular markings (counterparts of Salter's rain prints). b: Specimen from the Longmyndian Supergroup at Cardingmill Valley showing a densely-packed microbial mat of parallel-oriented filaments, preserved in both positive and negative relief on a bedding plane surface. Scale bar $2 \mathrm{~mm}$ for (a) and $1 \mathrm{~mm}$ for (b).

Figure 6. Filamentous bedding plane markings, representing microbial filaments preserved on bedding plane of fine-grained siliciclastic sediments of the c. 575 Ma Drook Formation, Newfoundland. a: Bedding plane view of 2 intertwined filamentous structures in positive relief preservation. These filaments are associated with a typical wrinkled and pustulose bedding plane surface. b: Abundant, straight, parallel-oriented microbial filaments, preserved in positive relief on a bedding plane top surface. It is also possible to observe the distinctive hook-shape of some filaments (arrowed), which indicates that these markings are unlikely to represent current lineations (cf. Arumberia; Mcllroy \& Walter, 1997). Coin is $20 \mathrm{~mm}$ in diameter. 
Figure 7. The three principal modes of preservation for Ediacaran macrofossils a: Holotype of Charnia masoni Ford preserved in negative relief on a bedding plane upper surface (cf. Conception Style of Narbonne, 2005). The preservation of fossils such as this beneath turbidites, rather than ashes is currently difficult to explain. From the Maplewell Series (c. $560 \mathrm{Ma}$ ), Charnwood Forest, Leicestershire, England. Specimen from the Leicester City Museum, Leicester, UK. b: Dickinsonia costata here preserves its upper surface morphology in negative relief on a bedding plane sole. This Flinders Style preservation has hitherto been explained by a combination of microbial mats and diagenetic pyrite formation (Gehling, 1999). From the c. 555 Ma Rawnsley Quartzite, Ediacara station, Flinders Ranges, South Australia. Specimen from the Roland Goldring Collection in the Oxford University Museum, OUM.ÁW.89. c: Three dimensionally preserved 'Nama-Style' specimens of Pteridinium, in a mode of preservation which has hitherto lacked widely applicable explanation. From the 550-543 Ma Nama Group, Namibia. Specimen from the Hans Pflug Collection, Geological Survey, Windhoek, Namibia. Scale bar $1 \mathrm{~cm}$ for (a)-(b) and $5 \mathrm{~cm}$ for $(\mathrm{c})$. 


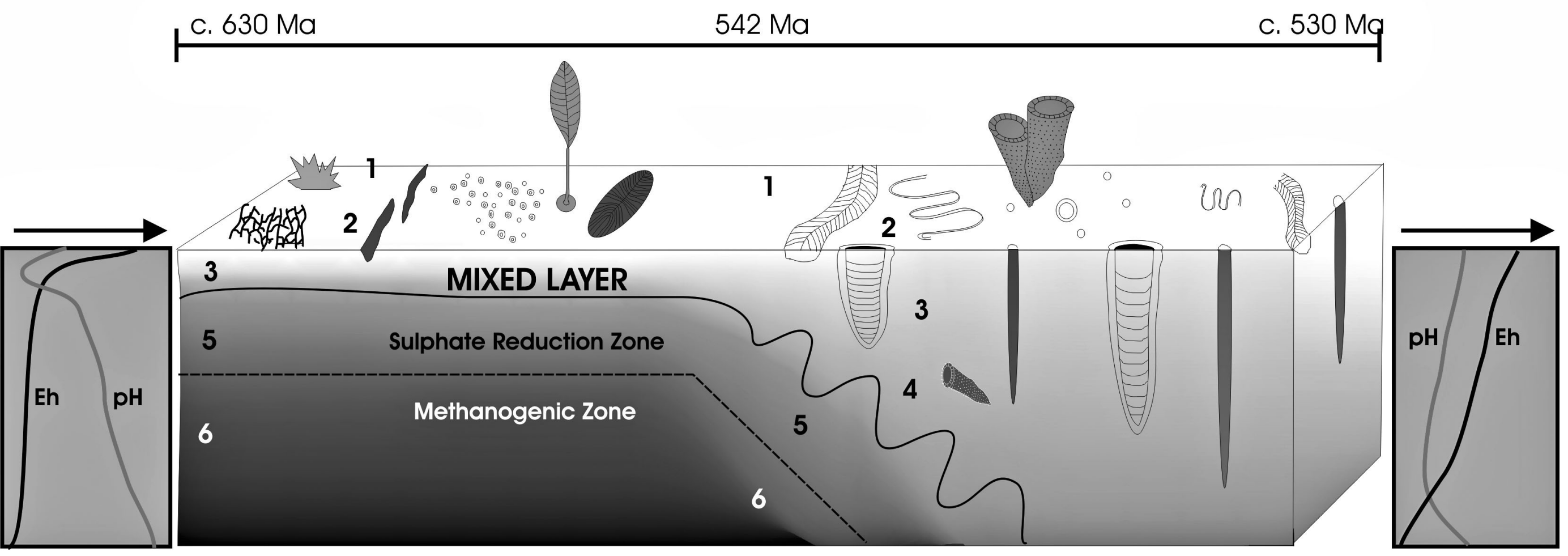

Fig. 1 

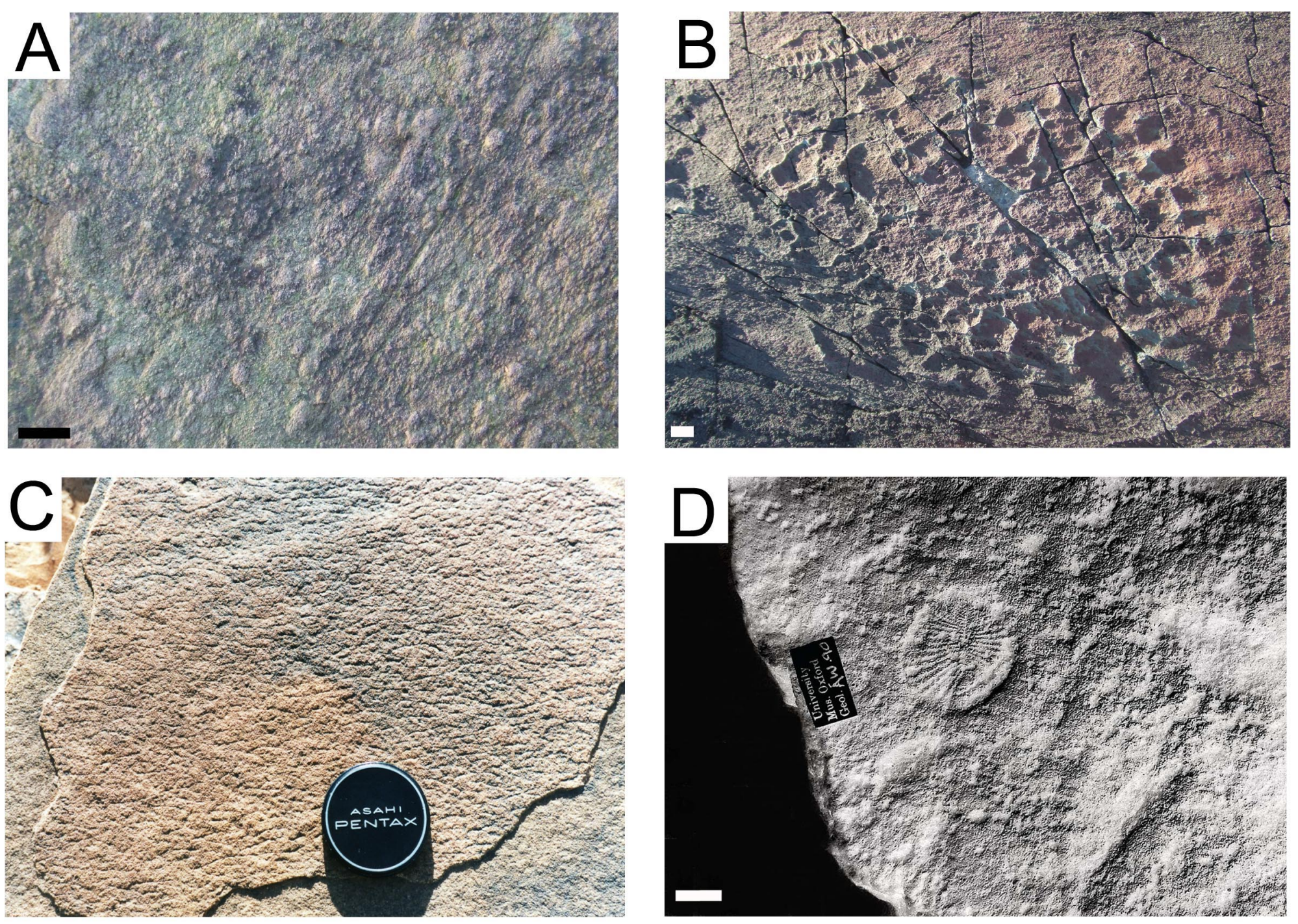

Fig. 2 


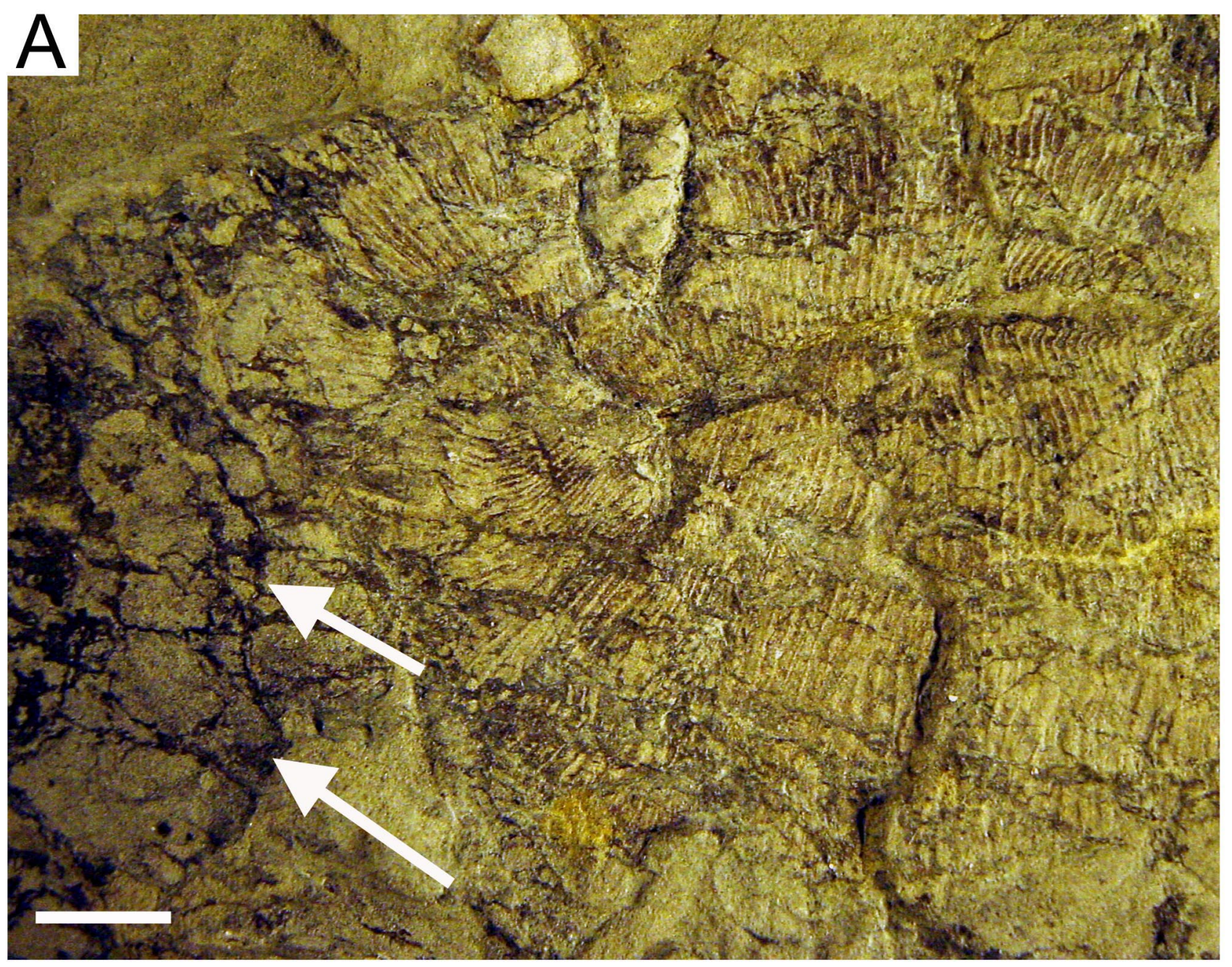

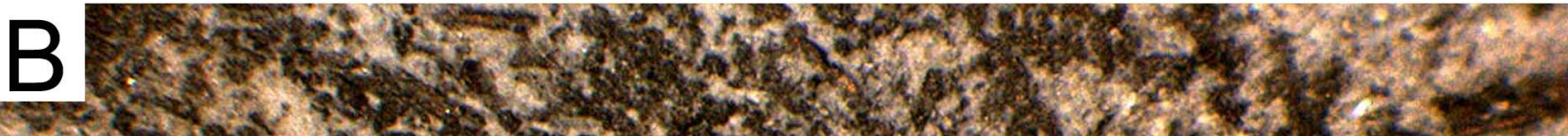
B.

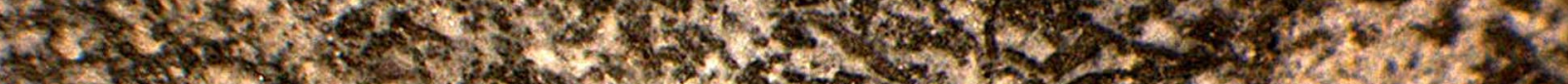

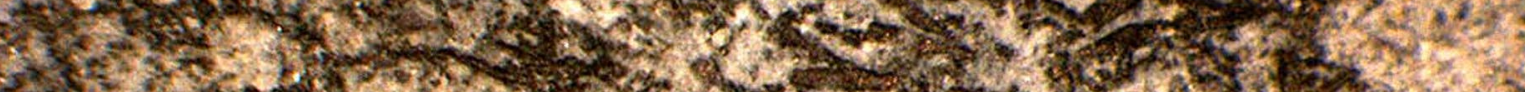

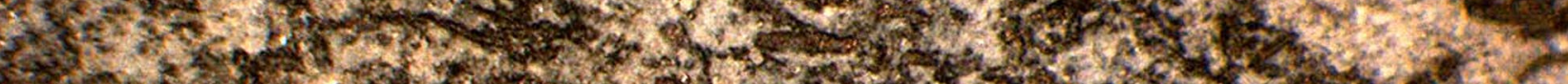

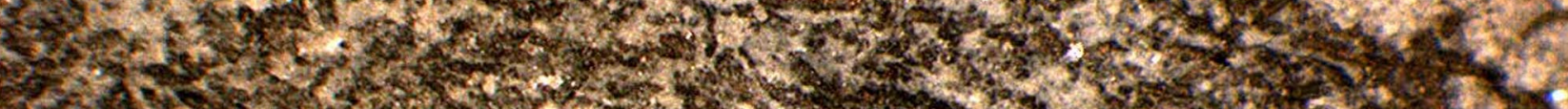

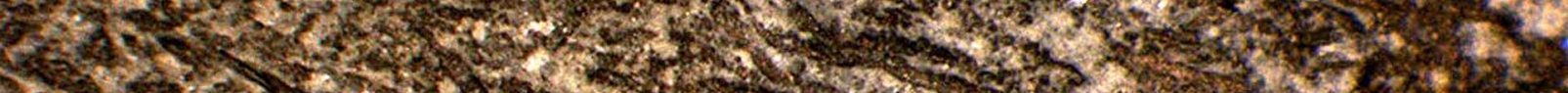

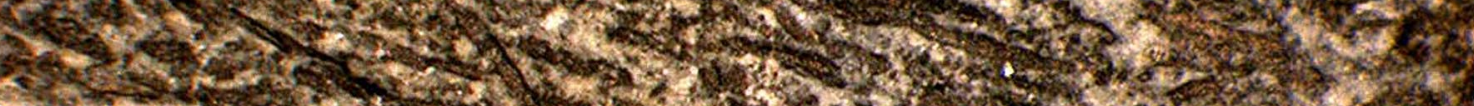

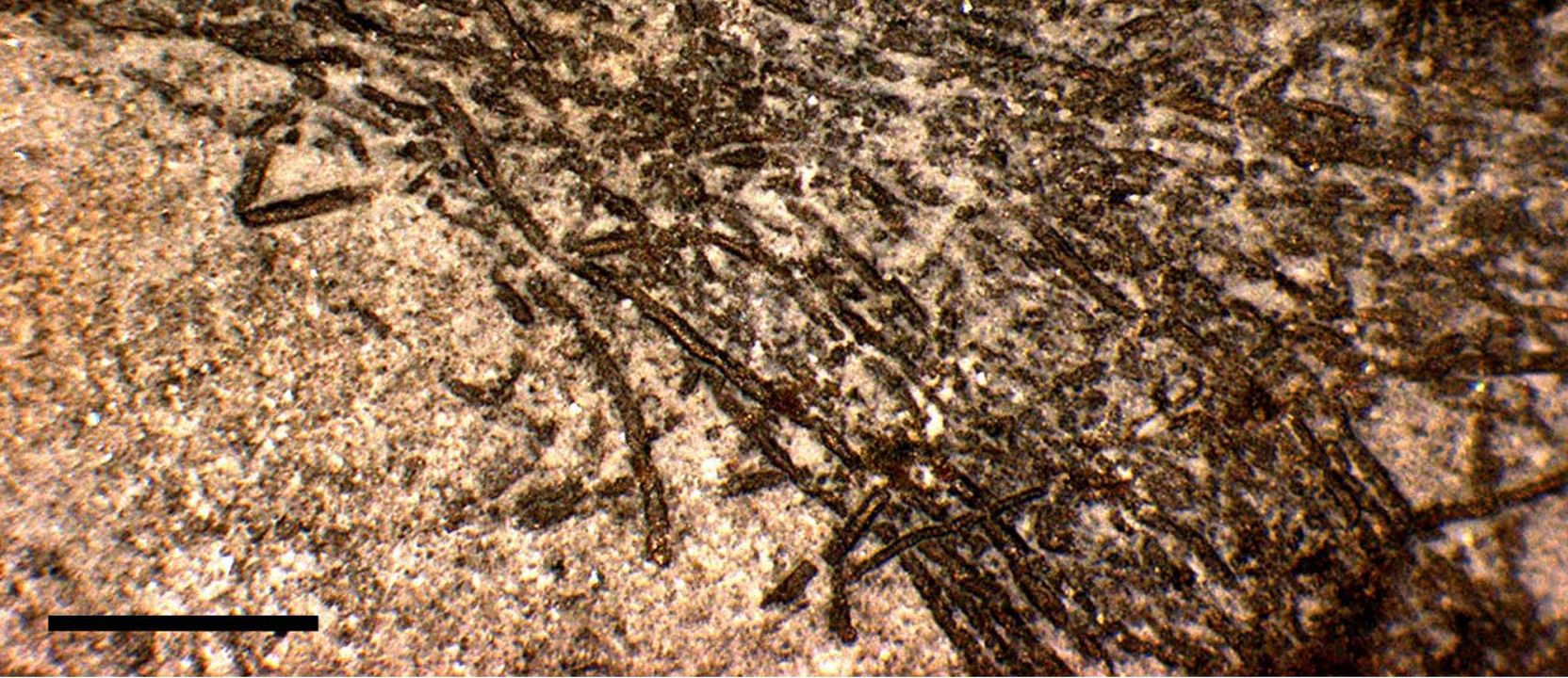



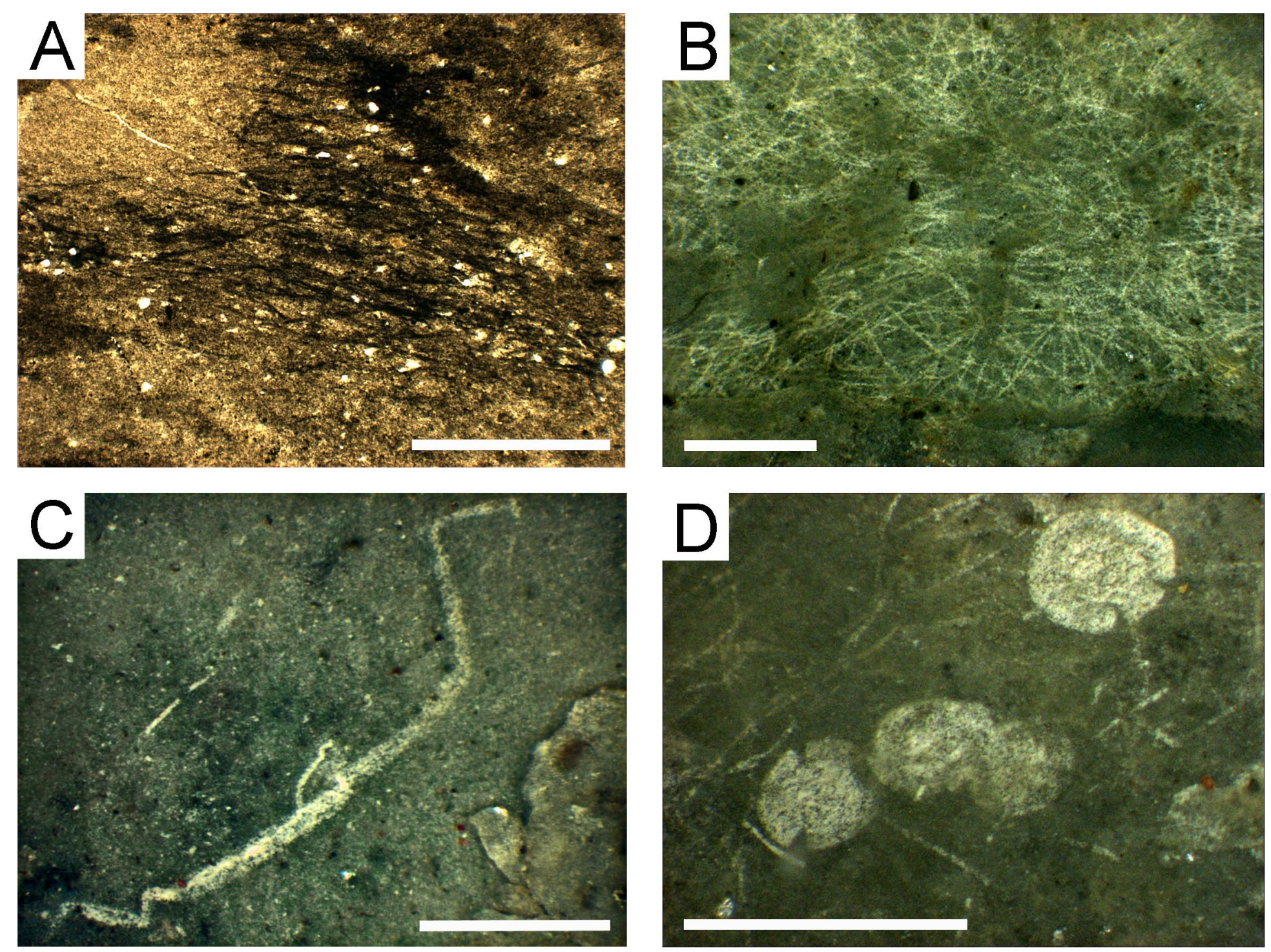

\section{Fig. 4}



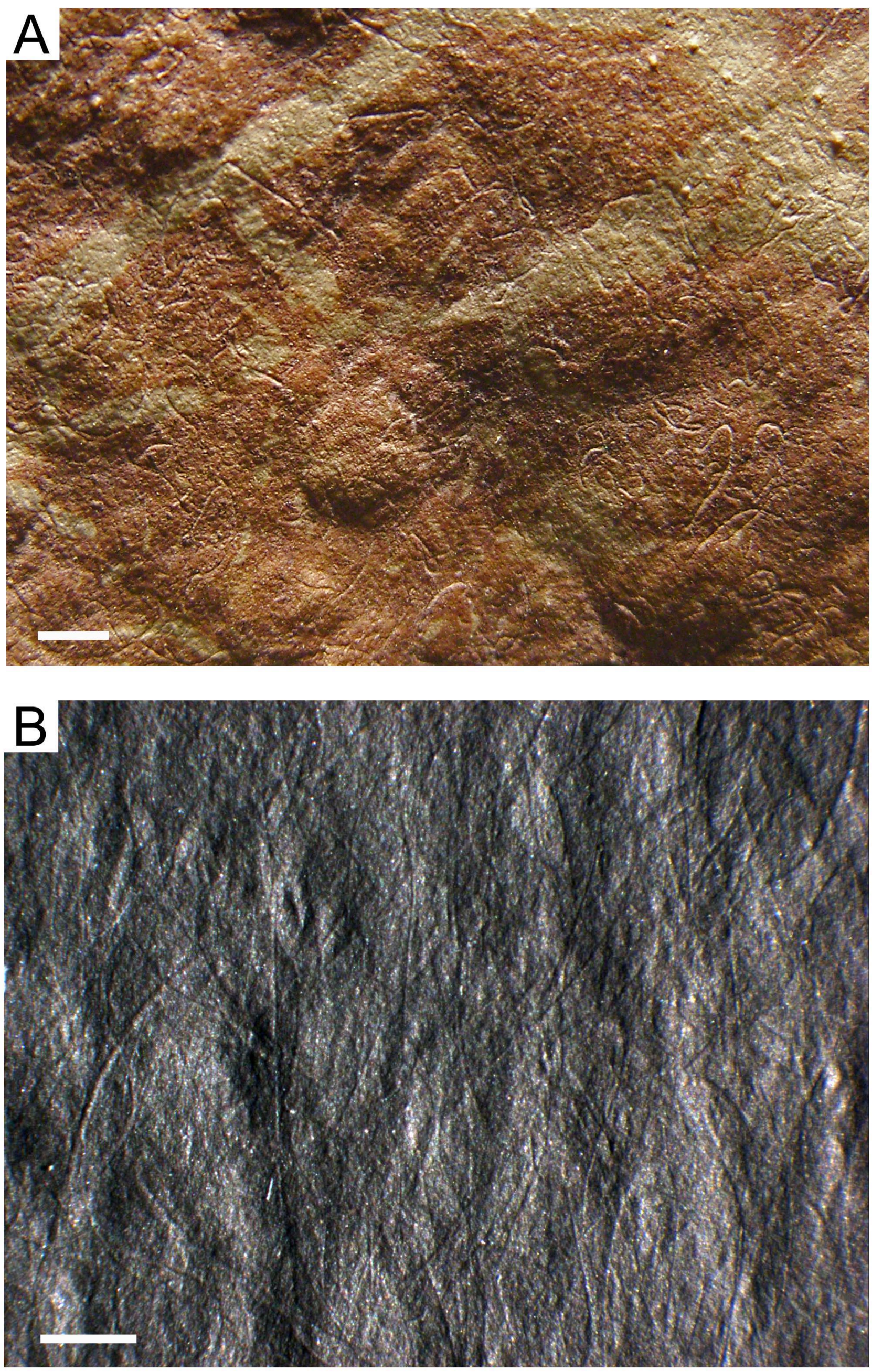

\section{Fig. 5}


A

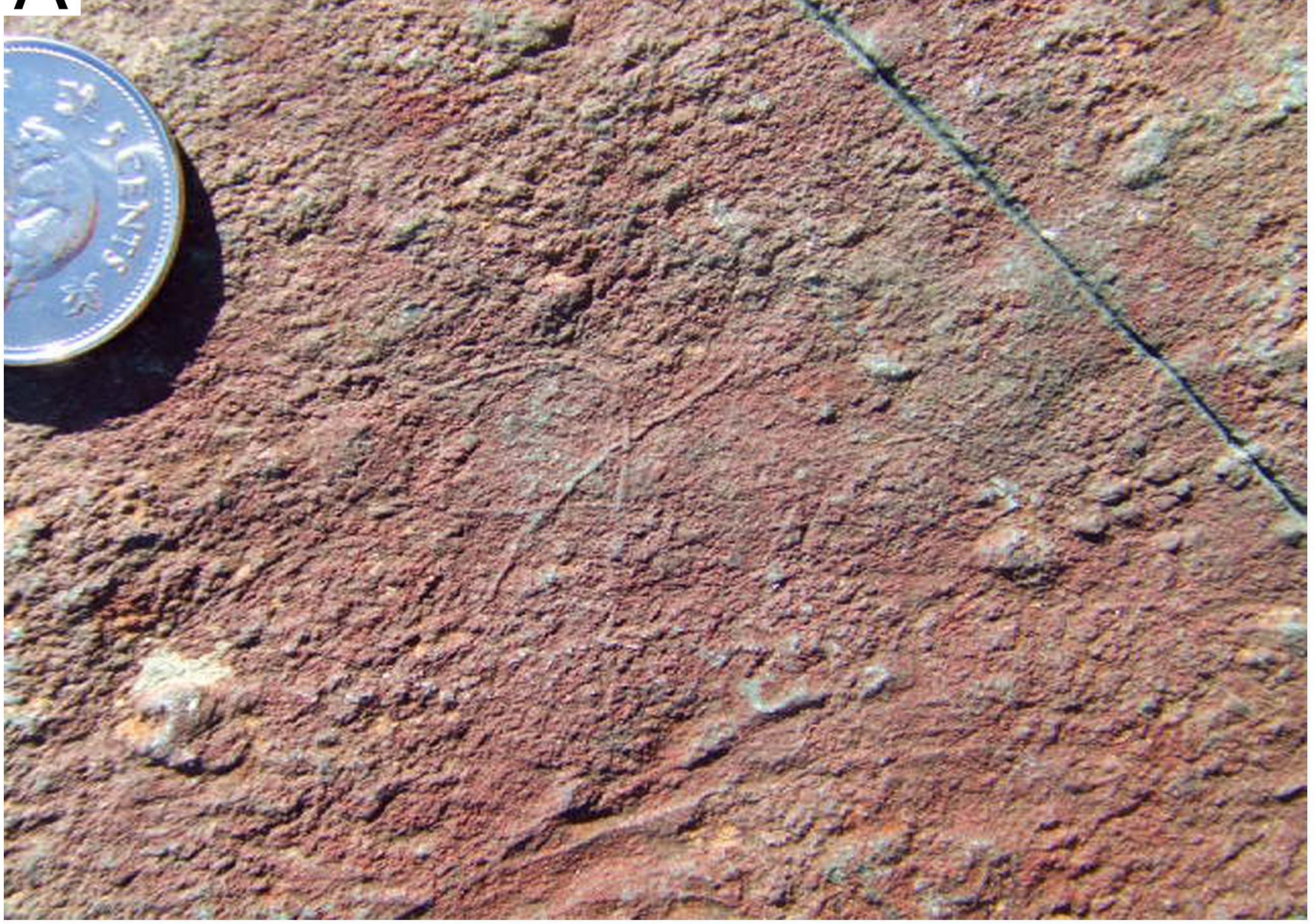

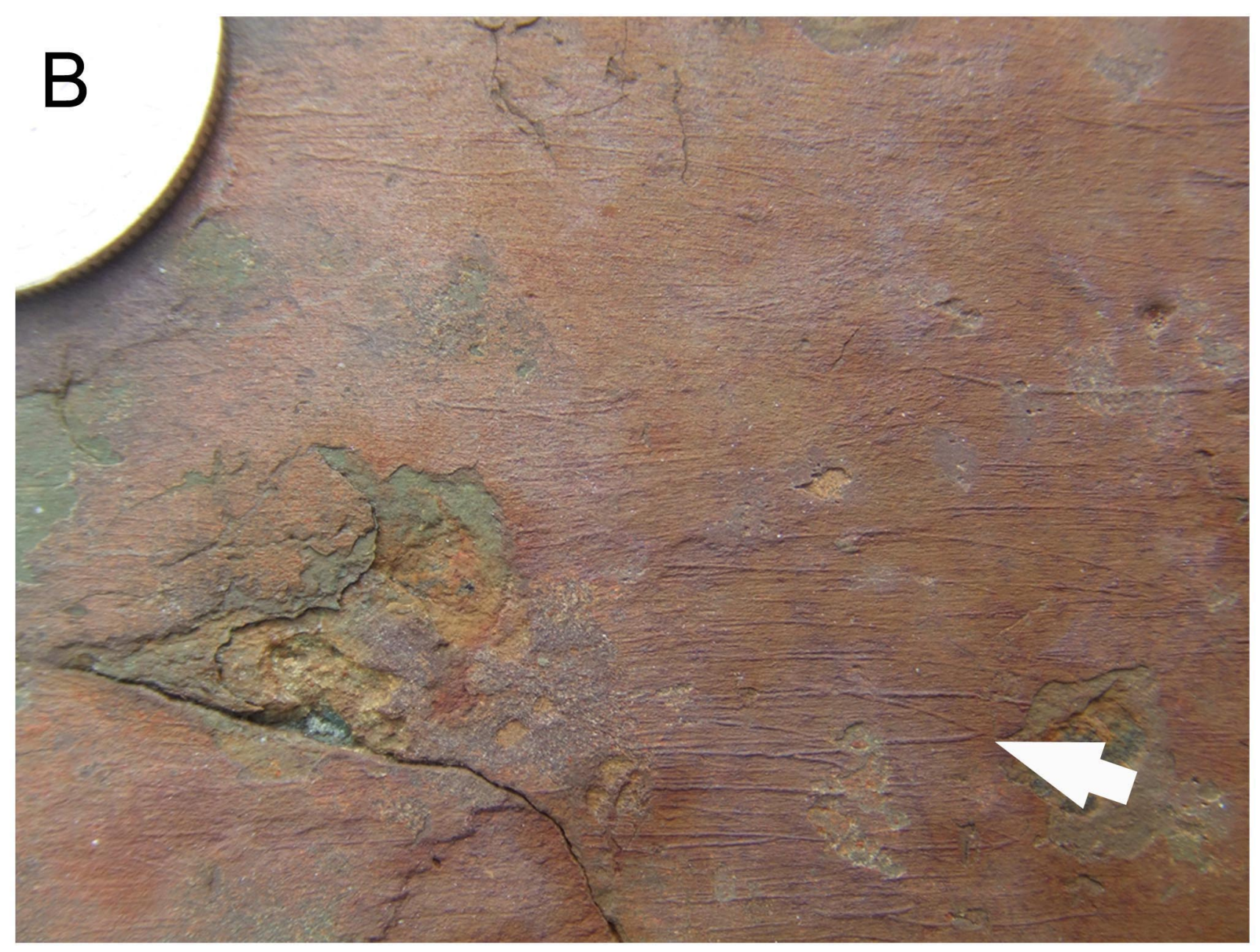




\section{A}

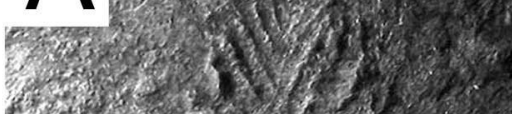

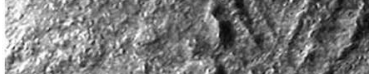

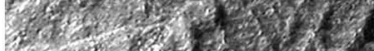

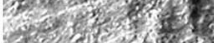

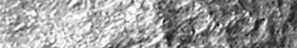

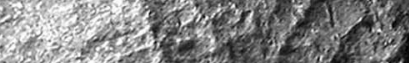
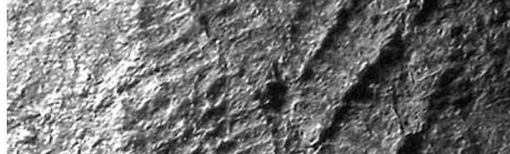

3.

2017.

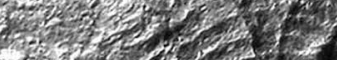

moln

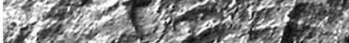

w. 1013

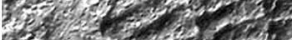

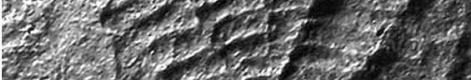

溶

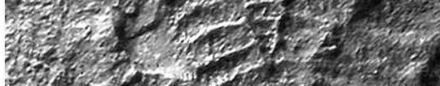

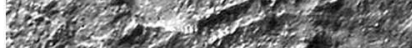

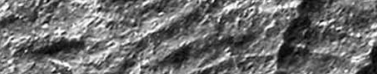

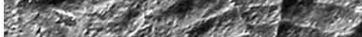

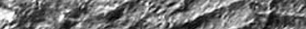

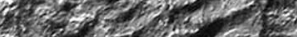

190101092

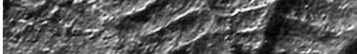

30 s.

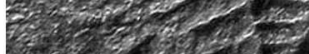

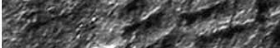

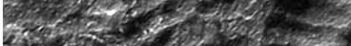

(1)
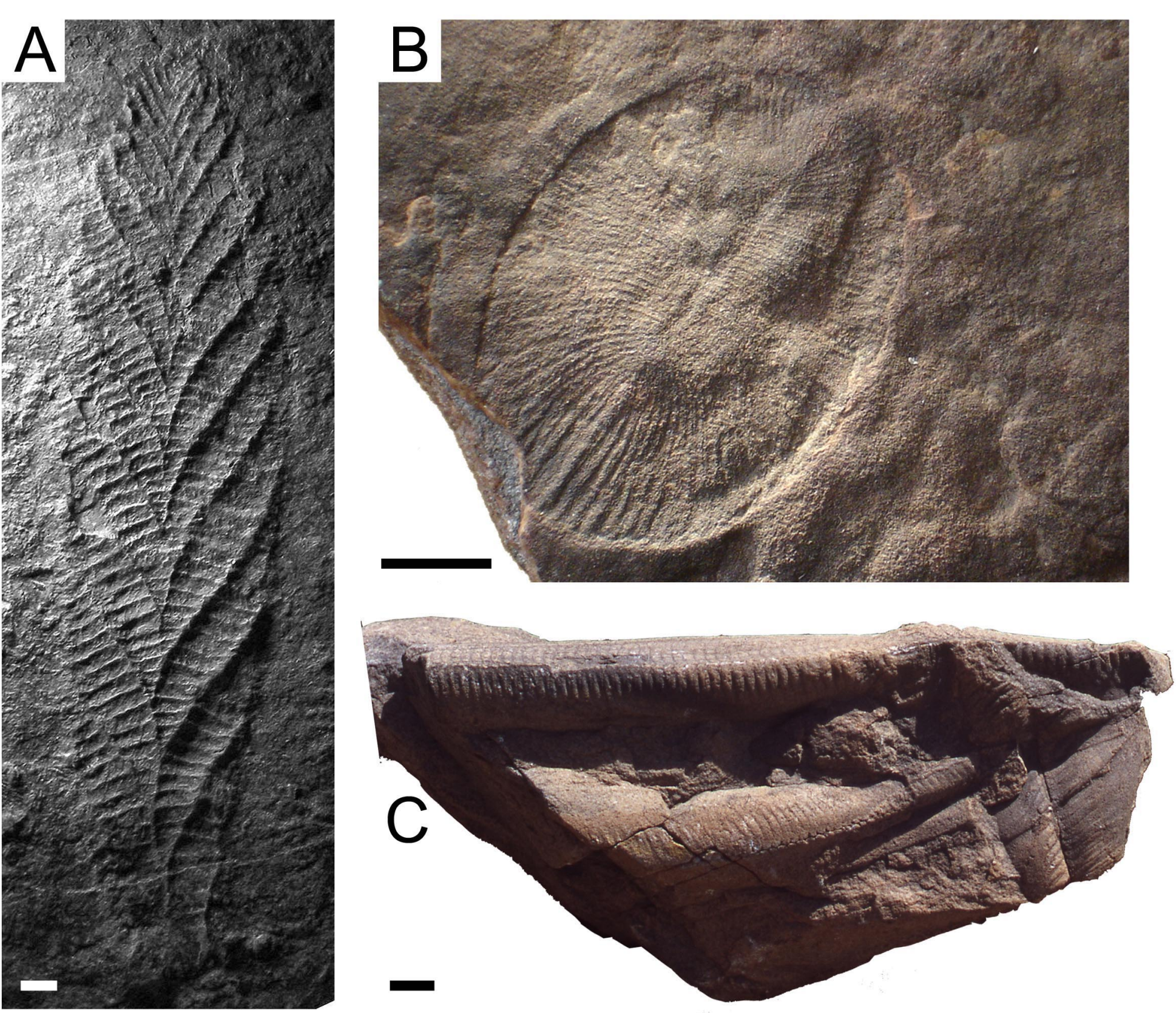

Fig. 7 